\title{
Vanadium(IV and v) Complexes of Schiff Bases and Reduced Schiff Bases Derived from the Reaction of Aromatic o-Hydroxyaldehydes and Diamines: Synthesis, Characterisation and Solution Studies
}

\author{
Isabel Correia, ${ }^{[a]}$ João Costa Pessoa, ${ }^{*[a]}$ M. Teresa Duarte, ${ }^{[a]}$ \\ M. Fátima Minas da Piedade, ${ }^{[a]}$ Tamás Jackush, ${ }^{[b]}$ Tamás Kiss, ${ }^{*[b]}$ \\ M. Margarida C. A. Castro, ${ }^{[\mathrm{cl}}$ Carlos F. G. C. Geraldes, ${ }^{[\mathrm{cl}]}$ and Fernando Avecilla ${ }^{[\mathrm{d}]}$
}

Keywords: Vanadium complexes / Schiff bases / Reduced Schiff bases / Crystal structures / Speciation

Several $\mathrm{sal}_{2}$ en-type reduced Schiff bases have been prepared from the reaction of 2 equiv. of salicylaldehyde (or derivatives) with ethylenediamine followed by reduction with $\mathrm{NaBH}_{4}$ and subsequently characterised. The water-soluble ligands $\left(\mathrm{SO}_{3} \text {-Sal }\right)_{2}$ en and $\mathrm{R}\left(\mathrm{SO}_{3} \text {-Sal }\right)_{2}$ en $\left(\mathrm{SO}_{3}\right.$-sal = salicylaldehyde-5-sulphonate) have been studied by $\mathrm{pH}$ potentiometry and ${ }^{1} \mathrm{H}$ NMR spectroscopy and the protonation constants of $\mathrm{R}\left(\mathrm{SO}_{3}-\mathrm{Sal}\right)_{2}$ en have been determined. The Schiff bases are more susceptible to hydrolysis than the corresponding reduced Schiff bases. The crystal structures of $\mathrm{H}_{2}(\mathrm{o} \text {-van })_{2} \mathrm{en}$ and $\mathrm{KH}(o \text {-van })_{2}$ en (o-van $=o$-vanillin) have been determined by X-ray diffraction. The vanadium(IV) complexes have been prepared and characterised by magnetic measurements and IR, UV/Vis and EPR spectroscopy. The colours, magnetic susceptibilities and IR spectra of the new vanadium(IV) complexes of the reduced Schiff bases now obtained suggest oligomeric/polymeric structures for the compounds while the corresponding $\mathrm{V}^{\mathrm{IV}} \mathrm{O}-\mathrm{Schiff}-$ base complexes are monomeric. The complexation of $\left[\mathrm{V}^{\mathrm{IV}} \mathrm{O}\right]^{2+}$ and $\left[\mathrm{V}^{\mathrm{V}} \mathrm{O}_{2}\right]^{+}$with $\mathrm{R}\left(\mathrm{SO}_{3}-\mathrm{Sal}\right)_{2} \mathrm{en}$ in aqueous solution has been studied by $\mathrm{pH}$ potentiometry, UV/Vis as well as by EPR spectroscopy for the $\mathrm{V}^{\mathrm{IV}} \mathrm{O}$ system and ${ }^{1} \mathrm{H}$ and ${ }^{51} \mathrm{~V}$ NMR spectroscopy for the $\mathrm{V}^{\mathrm{V}} \mathrm{O}_{2}$ system. Complex formation constants have been determined and binding modes have been proposed. $N, N^{\prime}$-ethylenebis(pyridoxylaminato) $\left(\operatorname{Rpyr}_{2} \mathrm{en}\right)$ has also been obtained and the structure of $\mathrm{Na}\left[\mathrm{V}^{\mathrm{V}} \mathrm{O}_{2}\left(\mathrm{Rpyr}_{2} \mathrm{en}\right)\right] \cdot \mathrm{CH}_{3} \mathrm{OH} \cdot 3 \mathrm{H}_{2} \mathrm{O}$ determined by X-ray diffraction. The $\mathrm{Rpyr}_{2} \mathrm{en}^{2-}$ ligand coordinates through both the $\mathrm{N}$-amine and $\mathrm{O}$-phenolate moieties in a symmetrical $\alpha$-cis type coordination mode, i.e. with both $O$ phenolato donors cis to the $\mathrm{O}$-oxo atoms and trans to each other.

(ㅇ Wiley-VCH Verlag GmbH \& Co. KGaA, 69451 Weinheim, Germany, 2005)

\section{Introduction}

The presence of vanadium in biological systems, its insulin-enhancing action ${ }^{[1-4]}$ and anticancer activity ${ }^{[5-7]}$ has driven a considerable amount of research. Particular interest has been given to the study of the potential benefits of vanadium compounds as oral insulin substitutes for the treatment of diabetes. ${ }^{[8-12]}$ Coordinated ligands should be able to improve the absorption and intracellular mobility of vanadium, reducing the dose necessary for producing equivalent effects. Several vanadium complexes of the dianionic tetradentate Schiff base $\mathrm{sal}_{2} \mathrm{en}\left(N, N^{\prime}\right.$-disalicylideneethylene-

[a] Centro Química Estrutural, Instituto Superior Técnico, Av. Rovísco Pais, 1049-001 Lisboa, Portugal

[b] Biocoordination Chemistry Research Group of the Hungarian Academy of Sciences, University of Szeged,

P. O. Box 440, 6701 Szeged, Hungary

[c] Departamento de Bioquímica, Centro de RMN e Centro de Neurociências e Biologia Celular, Universidade de Coimbra, 3001-401 Coimbra, Portugal

[d] Departamento de Química Fundamental, Universidade da Coruña,

Campus de A Zapateira, 15071 A Coruña, Spain

Supporting information for this article is available on the WWW under http://www.eurjic.org or from the author. diamine) type ligands have been proposed for use as insulinenhancing agents and for treatment of obesity and hypertension. ${ }^{[13-15]}$ Saminathan and Durai ${ }^{[13]}$ reported the ability of $\mathrm{V}^{\mathrm{IV}} \mathrm{O}\left(\mathrm{sal}_{2}\right.$ en) to reverse the hyperglycaemic condition of alloxan-induced diabetic rats, thereby exerting insulin-like action. However, the rats tended to become hypoglycaemic and withdrawal of treatment brought an immediate return of hyperglycaemia.

The $\mathrm{sal}_{2}$ en-type ligands present versatile steric, electronic and lipophilic properties. They may be easily prepared by the condensation of two compounds, namely an aromatic $o$-hydroxyaldehyde and a diamine, the hydrophilic-lipophilic balance being easily fine-tuned by choosing the appropriate amine precursors and ring substituents of the aldehyde.

In solution, Schiff base (SB) ligands have the disadvantage of their potential for hydrolysis. This instability can be overcome by reduction of the SB to give an amine. This presents interesting possibilities since the reduced SB will be more flexible and not forced to remain planar when coordinated to a metal centre. In this paper, we report the preparation of the SB and reduced SB ligands of salicylaldehyde, $o$-vanillin (o-van) and salicylaldehyde-5-sulphonate 
$\left(\mathrm{SO}_{3}\right.$-sal) with ethylenediamine and the preparation of their $\left[\mathrm{V}^{\mathrm{IV}} \mathrm{O}\right]^{2+}$ complexes which were characterised in the solid state and in solution.

Most of vanadium's biologically important reactions occur in water-based environments such as blood plasma and intracellular fluids. A knowledge of the distribution and chemical speciation of the vanadium compounds in aqueous solution is, therefore, of the utmost importance. Most of the $\mathrm{sal}_{2}$ en-type ligands and vanadium complexes prepared so far are not water-soluble. The compounds prepared using $\mathrm{SO}_{3}$-sal are, however, soluble in water and may, therefore, be particularly useful for therapeutic use.

The study of the moderately water-soluble Schiff base of pyridoxal and ethylenediamine $\left(\mathrm{pyr}_{2} \mathrm{en}\right)$ and its hydrolytically more stable reduced derivative $\mathrm{Rpyr}_{2} \mathrm{en}$ was reported in a previous paper. ${ }^{[15]}$ Both proved to be efficient binders of vanadium in the $+\mathrm{IV}$ and $+\mathrm{V}$ oxidation states. Several $\mathrm{V}^{\mathrm{IV}} \mathrm{O}$ - and $\mathrm{V}^{\mathrm{V}} \mathrm{O}_{2}-\mathrm{Rpyr}_{2}$ en complexes were prepared and their properties studied. One of these, $\left[\mathrm{V}^{\mathrm{V}} \mathrm{O}_{2}\left(\mathrm{HRpyr}_{2} \mathrm{en}\right)\right]$, was isolated in a crystalline form and structurally characterised by X-ray diffraction. Both ligands $\mathrm{pyr}_{2}$ en and $\mathrm{Rpyr}_{2}$ en were found to form basically similar complexes coordinating through two $\mathrm{O}_{\text {phenolate }}$ centres and two $\mathrm{N}_{\text {amine/imine }}$ centres. The solution speciation revealed that the reduced $\mathrm{SB}$ formed more stable complexes with both $\left[\mathrm{V}^{\mathrm{IV}} \mathrm{O}\right]^{2+}$ and $\left[\mathrm{V}^{\mathrm{V}} \mathrm{O}_{2}\right]^{+}$than the $\mathrm{SB}$ itself. EPR $\left(\mathrm{V}^{\mathrm{IV}} \mathrm{O}-\mathrm{Rpyr}_{2}\right.$ en system), ${ }^{1} \mathrm{H}$ and ${ }^{51} \mathrm{~V}$ NMR $\left(\mathrm{V}^{\mathrm{V}} \mathrm{O}_{2}-\mathrm{Rpyr}_{2}\right.$ en system) spectroscopic studies indicated the presence of various isomeric species in solution.

Some of the vanadium(IV) complexes synthesised and characterised in the present and in the previous study ${ }^{[15]}$ have been tested in vitro for their toxicity and insulin-mimetic behaviour, these are ${ }^{[16]} \mathrm{Cs}_{2}\left[\mathrm{~V}^{\mathrm{IV}} \mathrm{O}\left(\mathrm{SO}_{3} \text {-sal }\right)_{2} \mathrm{en}\right](\mathbf{8}),\left[\mathrm{V}^{\mathrm{I}-}\right.$ $\left.{ }^{\mathrm{V}} \mathrm{O}\left(\mathrm{Rsal}_{2} \mathrm{en}\right)\right](9),\left[\mathrm{V}^{\mathrm{IV}} \mathrm{O}\left(\mathrm{pyr}_{2}\right.\right.$ en $\left.)\right]$ and $\left[\mathrm{V}^{\mathrm{IV}} \mathrm{O}\left(\mathrm{Rpyr}_{2} \mathrm{en}\right)\right]$. At vanadium concentrations below $10 \mu \mathrm{M}$ none of the compounds were toxic and they all proved to be effective with respect to the insulin-mimetic activity which was tested as the ability of vanadium compounds to trigger glucose uptake by cells. In that study, compound $\mathbf{8}$ was considered one of the most promising compounds with respect to its insulin-mimetic behaviour and low toxicity in the physiological concentration range. ${ }^{[16]}$

\section{Results and Discussion}

\section{Synthesis and Characterisation}

The Schiff bases 1-3 (see Scheme 1) were prepared in high yields $(>75 \%)$ by the condensation of 2 equiv. of the appropriate aldehyde derivative with 1 equiv. of ethylenediamine. Treatment of these condensation products with sodium borohydride resulted in the reduction of the two imine bonds, yielding the reduced Schiff bases 4-7 (Scheme 1). All compounds gave satisfactory elemental analyses and were

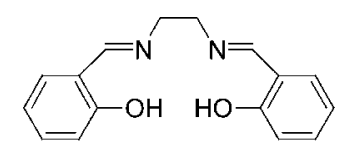

sal $_{2}$ en 1

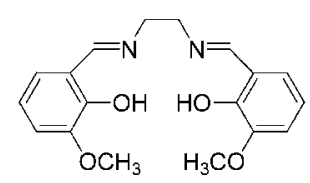

$(o-v a n)_{2}$ en 2

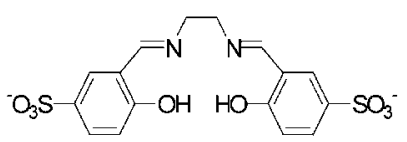

$\left(\mathrm{SO}_{3}-\mathrm{Sal}\right)_{2}$ en 3

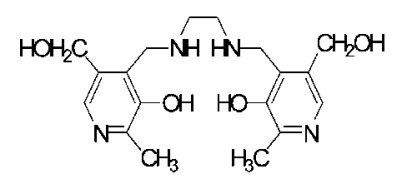

Rpyr $_{2}$ en 7

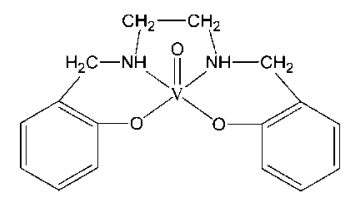

$\mathbf{V}^{\mathrm{IV}} \mathbf{O ( \operatorname { R s a l } _ { 2 } \mathrm { en } )} 9$

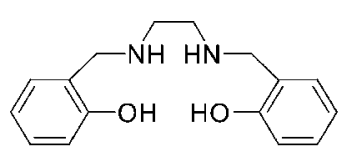

Rsal 2 en 4

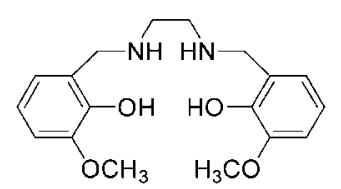

$\mathbf{R}(o \text {-van })_{2}$ en 5

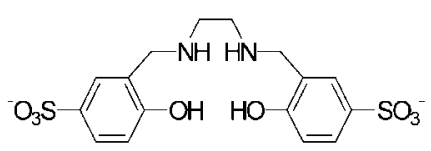

$\mathbf{R}\left(\mathrm{SO}_{3} \text {-sal) }\right)_{2}$ en 6

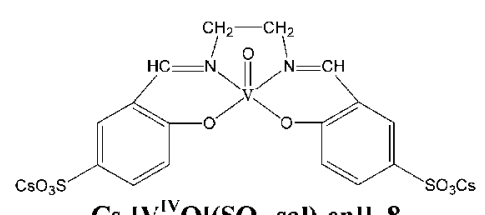

$\mathrm{Cs}_{2}\left[\mathrm{~V}^{\mathrm{IV}} \mathrm{O}\left[\left(\mathrm{SO}_{3}-\mathrm{Sal}\right)_{2} \mathrm{en}\right]\right] 8$

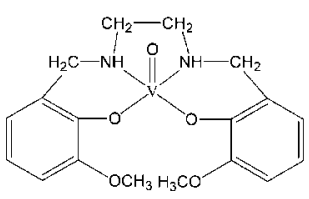

$\mathrm{V}^{\mathrm{IV}} \mathrm{O}\left[\mathrm{R}(o-\mathrm{van})_{2} \mathrm{en}\right] \mathbf{1 0}$

Scheme 1. Ligands and $\left[\mathrm{V}^{\mathrm{IV}} \mathrm{O}\right]^{2+}$ complexes prepared and characterised in this work 
characterised by ${ }^{1} \mathrm{H}$ NMR spectroscopy and mass spectrometry. Two types of crystals suitable for X-ray diffraction studies were obtained for $\mathbf{2}$.

By treatment of 3-5 with oxovanadium(IV) salts, [ $\left.\mathrm{V}^{\mathrm{IV}} \mathrm{O}\right]$ complexes with an $\mathrm{N}_{2} \mathrm{O}_{2}$ binding mode were obtained in good yields, namely $\left[\mathrm{V}^{\mathrm{IV}} \mathrm{O}\left\{\left(\mathrm{SO}_{3} \text {-sal }\right)_{2} \mathrm{en}\right\}\right](\mathbf{8}){ }^{[17]}\left[\mathrm{V}^{\mathrm{IV}} \mathrm{O}-\right.$ (Rsal $\left.\left.{ }_{2} \mathrm{en}\right)\right]$ (9) and $\left[\mathrm{V}^{\mathrm{IV}} \mathrm{O}\left\{\mathrm{R}(o-\mathrm{van})_{2} \mathrm{en}\right\}\right]$ (10). The complexes were characterised by elemental analysis, IR and UV/ Vis spectroscopy. All our efforts to characterise the compounds obtained from the reaction of $\mathbf{6}$ with $\left[\mathrm{V}^{\mathrm{IV}} \mathrm{O}\right]^{2+}$ were unsuccessful. Solids were obtained but no satisfactory formulation could be deduced. Compound $\mathbf{1 1}$ was obtained after slow concentration of a methanolic solution which contained a $\mathrm{V}^{\mathrm{V}}$ salt and compound 7.

\section{X-ray Diffraction Studies}

\section{$\mathrm{H}_{2}(\mathrm{o}-\mathrm{van})_{2} \mathrm{en}(2 \mathrm{~A})$ and $\mathrm{KH}(\mathrm{o}-\mathrm{van})_{2} \mathrm{en} \cdot 2 \mathrm{H}_{2} \mathrm{O}(2 \mathrm{~B})$}

ORTEP diagrams of 2A and 2B are presented in Figure 1 and selected bond lengths and angles are given in Table 1 . A similar crystal structure for $\mathbf{2 A}$ has already been reported ${ }^{[18]}$ but we have included our data since it is of a better resolution (taking into account the $R$ and e.s.d. values; we also included the hydrogen atoms in the refinement). The molecular structure of $\mathbf{2 A}$ agrees with the published data ${ }^{[18]}$ and both exhibit two geometry-determined intramolecular $\mathrm{H}$-bonds between the $\mathrm{N}_{\text {imine }}$ and the $\mathrm{O}_{\text {phenolic }}$ centres in both sides of the molecule $[\mathrm{O}-\mathrm{H} \cdots \mathrm{N}$ 2.576(3), 2.608(3) $\AA$ with angles of $147.4(2)^{\circ}$ and $146.8(2)^{\circ}$ which dictate the molecular configuration and an $\mathrm{N}-\mathrm{C}-\mathrm{C}-\mathrm{N}$ torsion angle of $-163.0(2)^{\circ}\left(-160.91^{\circ}\right.$ in ref. $\left.\left.{ }^{[18]}\right)\right]$. The bond lengths and angles do not show any significant deviation from the expected values in similar compounds. ${ }^{[15,19,20]}$ Another structure for $\mathrm{H}_{2}$ (o-van $)_{2}$ en has recently been reported. ${ }^{[21]}$ However, it is impossible to access this report to make adequate comparisons. ${ }^{[22]}$

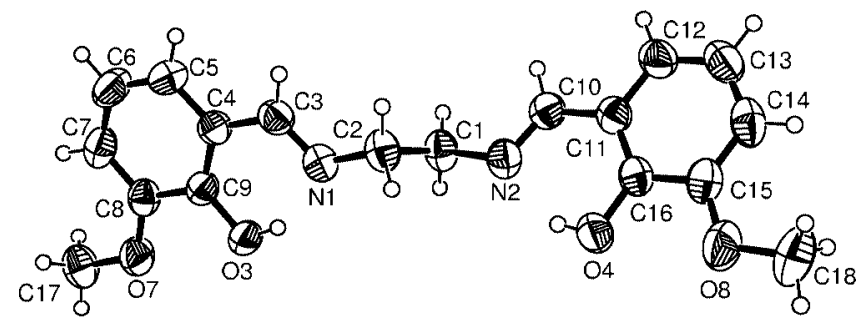

$\mathbf{A}$

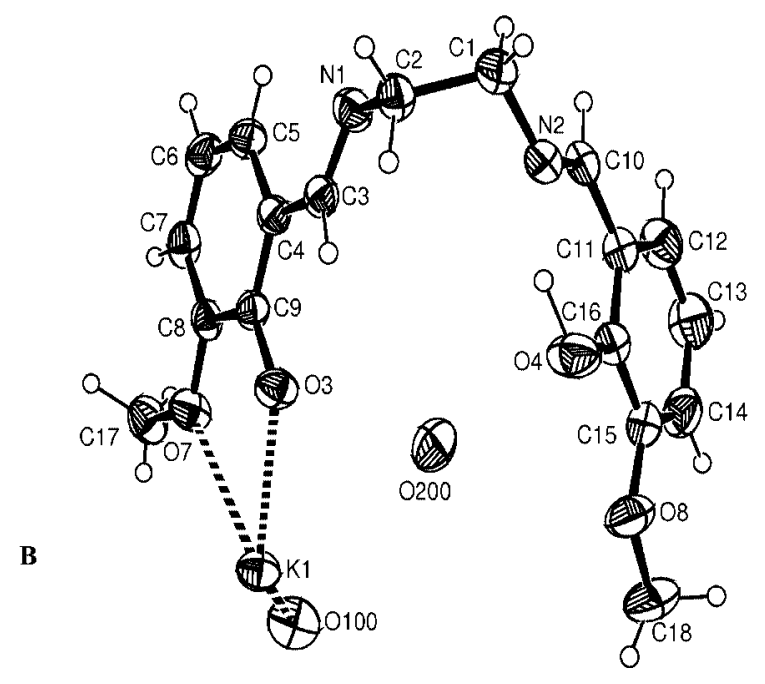

Figure 1. ORTEP diagrams of $\mathrm{H}_{2}(o \text {-van })_{2}$ en (2A) and $\mathrm{KH}(o$-van) ${ }_{2} \mathrm{en} \cdot 2 \mathrm{H}_{2} \mathrm{O}(2 \mathrm{~B})$, showing the atom labelling scheme; thermal ellipsoids of the non-hydrogen atoms have been drawn at the $40 \%$ probability level

The molecular structure of $\mathbf{2 A}$ is comparable with that of $\mathbf{2 B}$, the latter being the same organic moiety but crystallised as an ionic pair with $\mathrm{K}^{+}$and two water molecules of crystallisation. In $\mathbf{2 B}$, the presence of $\mathrm{K}^{+}$changes the type of intramolecular H-bonds formed, thus promoting a totally different conformation of the organic moiety. One of

Table 1. Selected bond lengths $[\AA]$ and angles $\left[{ }^{\circ}\right]$ for $\mathrm{H}_{2}(o \text {-van })_{2}$ en $(\mathbf{2 A})$ and $\mathrm{KH}(o \text {-van })_{2} \mathrm{en} \cdot 2 \mathrm{H}_{2} \mathrm{O}(\mathbf{2 B})$; \# symmetry operation: $-x,-y,-\mathrm{Z}$

\begin{tabular}{|c|c|c|c|c|c|c|c|}
\hline \multicolumn{2}{|c|}{$\mathrm{H}_{2}(o \text {-van })_{2} \mathrm{en}$} & \multicolumn{2}{|c|}{$\mathrm{KH}(o \text {-van })_{2} \mathrm{en} \cdot 2 \mathrm{H}_{2} \mathrm{O}$} & \multicolumn{2}{|c|}{$\mathrm{H}_{2}(o \text {-van })_{2} \mathrm{en}$} & \multicolumn{2}{|c|}{$\mathrm{KH}(o \text {-van })_{2} \mathrm{en} \cdot 2 \mathrm{H}_{2} \mathrm{O}$} \\
\hline \multicolumn{4}{|c|}{ Bond lengths } & \multicolumn{4}{|c|}{ Angles } \\
\hline $\mathrm{N}(1)-\mathrm{C}(2)$ & $1.461(3)$ & $\mathrm{N}(2)-\mathrm{C}(1)$ & $1.509(6)$ & $\mathrm{C}(2)-\mathrm{N}(1)-\mathrm{C}(3)$ & $119.0(2)$ & $\mathrm{C}(1)-\mathrm{N}(2)-\mathrm{C}(10)$ & $135.2(4)$ \\
\hline $\mathrm{N}(1)-\mathrm{C}(3)$ & $1.275(4)$ & $\mathrm{N}(2)-\mathrm{C}(10)$ & $1.282(6)$ & $\mathrm{C}(3)-\mathrm{C}(4)-\mathrm{C}(5)$ & $120.4(2)$ & $\mathrm{C}(10)-\mathrm{C}(11)-\mathrm{C}(16)$ & $117.0(5)$ \\
\hline $\mathrm{O}(3)-\mathrm{C}(8)$ & $1.347(3)$ & $\mathrm{O}(4)-\mathrm{C}(16)$ & $1.305(6)$ & $\mathrm{N}(1)-\mathrm{C}(3)-\mathrm{C}(4)$ & $121.4(2)$ & $\mathrm{N}(2)-\mathrm{C}(10)-\mathrm{C}(11)$ & $135.0(4)$ \\
\hline $\mathrm{N}(2)-\mathrm{C}(10)$ & $1.265(4)$ & $\mathrm{O}(3)-\mathrm{C}(8)$ & $1.260(5)$ & $\mathrm{O}(3)-\mathrm{C}(5)-\mathrm{C}(4)$ & $122.0(2)$ & $\mathrm{O}(4)-\mathrm{C}(16)-\mathrm{C}(11)$ & $111.3(4)$ \\
\hline \multirow[t]{3}{*}{$\mathrm{O}(4)-\mathrm{C}(16)$} & $1.355(3)$ & $\mathrm{N}(1)-\mathrm{C}(3)$ & $1.156(6)$ & $\mathrm{N}(1)-\mathrm{C}(2)-\mathrm{C}(1)$ & $107(2)$ & $\mathrm{N}(2)-\mathrm{C}(1)-\mathrm{C}(2)$ & $123.4(3)$ \\
\hline & & $\mathrm{O}(3)-\mathrm{K}(1)$ & $2.403(4)$ & $\mathrm{C}(4)-\mathrm{C}(9)-\mathrm{O}(3)$ & 122.3 & $\mathrm{C}(9)-\mathrm{C}(8)-\mathrm{O}(3)$ & $111.3(4)$ \\
\hline & & $\mathrm{O}(4)^{\#}-\mathrm{K}(1)$ & $2.497(3)$ & & & $\mathrm{C}(11)-\mathrm{C}(16)-\mathrm{O}(4)$ & $110.8(4)$ \\
\hline$C(3)-C(4)$ & $1.458(4)$ & $\mathrm{C}(10)-\mathrm{C}(11)$ & $1.488(7)$ & & & & \\
\hline$C(4)-C(5)$ & $1.402(4)$ & $\mathrm{C}(11)-\mathrm{C}(12)$ & $1.413(7)$ & & & & \\
\hline $\mathrm{C}(4)-\mathrm{C}(8)$ & $1.399(3)$ & $\mathrm{C}(11)-\mathrm{C}(16)$ & $1.182(5)$ & & & & \\
\hline$C(5)-C(8)$ & $1.411(3)$ & $C(16)-C(15)$ & $1.422(7)$ & & & & \\
\hline $\mathrm{O}(7)-\mathrm{C}(17)$ & $1.422(3)$ & $\mathrm{O}(8)-\mathrm{C}(18)$ & $1.425(7)$ & & & & \\
\hline$C(7)-C(6)$ & $1.388(5)$ & $\mathrm{C}(14)-\mathrm{C}(13)$ & $1.156(7)$ & & & & \\
\hline$C(6)-C(5)$ & $1.364(5)$ & $\mathrm{C}(13)-\mathrm{C}(12)$ & $1.405(8)$ & & & & \\
\hline$C(2)-C(1)$ & $1.527(4)$ & $\mathrm{C}(1)-\mathrm{C}(2)$ & $1.768(7)$ & & & & \\
\hline $\mathrm{O}(3), \mathrm{N}(1)$ & $2.600(3)$ & $\mathrm{O}(4), \mathrm{N}(2)$ & $4.126(5)$ & & & & \\
\hline $\mathrm{O}(4), \mathrm{N}(2)$ & $2.567(3)$ & $\mathrm{O}(3), \mathrm{N}(1)$ & $2.554(5)$ & & & & \\
\hline
\end{tabular}


the intramolecular interactions is retained $[\mathrm{O}(4)-\mathrm{H} \cdots \mathrm{N}(2)$ 2.556(5) $\AA$ ] but the other is lost due to the direct interaction of the phenolic oxygen atom with the $\mathrm{K}^{+}$cation. A completely different conformation is thus obtained with an $\mathrm{N}-$ $\mathrm{C}-\mathrm{C}-\mathrm{N}$ torsion angle of $-71.8(5)^{\circ}$. In the crystal structure of $\mathbf{2 B}$, the molecules pack as pseudo dimers due to the interactions with the $\mathrm{K}^{+}$cations and an extensive $\mathrm{H}$-bonding system is promoted by the water molecules (see section ESIA of the Supporting information for details).Figure ESI-1 (Supporting information) shows the cubic-like cage formed by the hydroxyl-oxygen, the $\mathrm{K}^{+}$ion and the $\mathrm{O}$ atoms of the water molecules. The coordination number of $\mathrm{K}^{+}$is six and it adopts a twisted trigonal-prismatic geometry (where the $\mathrm{O}_{x} \cdots \mathrm{K}^{+}$interactions, with $x=$ hydroxy or water, range from 2.699 to $3.054 \AA$ ).

\section{$\mathrm{Na}\left[\mathrm{V}^{\mathrm{V}} \mathrm{O}_{2}\left(\mathrm{Rpyr}_{2} \mathrm{en}\right)\right] \cdot \mathrm{CH}_{3} \mathrm{OH} \cdot 3 \mathrm{H}_{2} \mathrm{O}$ (11)}

$\mathrm{Rpyr}_{2}$ en is stable to hydrolysis and ${ }^{1} \mathrm{H}$ and ${ }^{51} \mathrm{~V}$ NMR spectroscopic studies for the $\mathrm{V}^{\mathrm{V}} \mathrm{O}_{2}-\mathrm{Rpyr}_{2}$ en system indicated the presence of various complexes in solution, namely $\alpha$-cis- and $\beta$-cis-type isomers ${ }^{[15]}$ (Scheme 2 ). The pyridinium $\mathrm{N}$ atoms of the pyridoxal rings do not take part in the coordination but are involved in acid-base reactions which affect the number, type and relative amount of the isomers of the $\mathrm{V}^{\mathrm{V}} \mathrm{O}_{2}-\mathrm{Rpyr}_{2}$ en complexes present in solution. ${ }^{[15]} \mathrm{DFT}$ calculations provided sensible molecular structures and the energy values for the various $\alpha$-cis- and $\beta$-cis-type isomeric complexes differ by less than $4 \mathrm{kcal} \mathrm{mol}^{-1}$, confirming that both types may coexist in solution. The $\alpha$-cis isomer is symmetric and corresponds to the structure presently determined by X-ray diffraction.

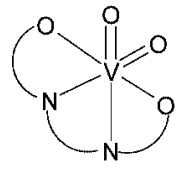

$\alpha-c i s$

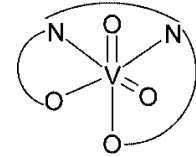

$\beta$-cis
Scheme 2. Schematic representation of the binding mode of the $\alpha$ and $\beta$-cis isomers in the present $\mathrm{VO}_{2}{ }^{+}$complexes

The structure of $\left[\mathrm{V}^{\mathrm{V}} \mathrm{O}_{2}\left(\mathrm{HRpyr}_{2} \mathrm{en}\right)\right]$ (12) obtained from aqueous solutions at $\mathrm{pH} \approx 7$ was reported previously. ${ }^{[15]}$ The ligand coordinates to the $\mathrm{V}^{\mathrm{V}}$ centre through the two $\mathrm{N}_{\text {amine }}$ and two $\mathrm{O}_{\text {phenolate }}$ atoms. The molecule is neutral and only one of the pyridine $\mathrm{N}$ atoms is protonated. From methanolic solutions containing the ligand and a different metal precursor $\left(\mathrm{Bu}_{4} \mathrm{NVO}_{3}\right)$, a new compound was obtained, namely $\mathrm{Na}\left[\mathrm{V}^{\mathrm{V}} \mathrm{O}_{2}\left(\mathrm{Rpyr}_{2}\right.\right.$ en) $] \cdot \mathrm{CH}_{3} \mathrm{OH} \cdot 3 \mathrm{H}_{2} \mathrm{O}$ (11), its molecular structure is shown in Figure 2 and some selected bond lengths and angles are included in Table 2.Both $\mathbf{1 1}$ and 12 correspond to the symmetrical $\alpha$-cis-type complex. ${ }^{[15]}$ The molecular structures are similar and the difference that must be emphasised is that in the present compound 11, both pyridinic $\mathrm{N}$ atoms are deprotonated. Thus, both halves of the ligand become equivalent whereas they are different in 12. The complex molecule in $\mathbf{1 1}$ is anionic and there is an $\mathrm{Na}^{+}$counterion in the crystal structure as well as one methanol and three water molecules.

The $\mathrm{V}-\mathrm{O}_{\text {oxo }}, \mathrm{V}-\mathrm{O}_{\text {phenolate }}$ and $\mathrm{V}-\mathrm{N}_{\text {amine }}$ bond lengths are similar in $\mathbf{1 1}$ and $\mathbf{1 2}$ but (i) the difference between the two $\mathrm{V}-\mathrm{O}_{\text {oxo }}$ internuclear distances is $0.019 \AA$ in $\mathbf{1 1}$ (not significant within a $3 \sigma$ criterion) while it is $0.056 \AA$ in $\mathbf{1 2}$ (this is probably due to different $\mathrm{H}$-bonding interactions of the $\mathrm{O}_{\text {oxo }}$ atoms in $\mathbf{1 1}$ and 12) and (ii) in the two halves of $\left[\mathrm{V}^{\mathrm{V}} \mathrm{O}_{2}\left(\mathrm{Rpyr}_{2} \mathrm{en}\right)\right]^{-}$, the two $\mathrm{V}-\mathrm{O}_{\text {phenolate }}$ and $\mathrm{V}-\mathrm{N}_{\text {amine }}$ bond lengths differ by 0.003 (not significant) and $0.02 \AA$, respectively, while they differ by 0.07 and $0.06 \AA$, respectively, in $\left[\mathrm{V}^{\mathrm{V}} \mathrm{O}_{2}\left(\mathrm{HRpyr}_{2} \mathrm{en}\right)\right]$. This is due to the deprotonation of both pyridine $\mathrm{N}$ atoms in $\mathbf{1 1}$. The similarity of both halves of the ligand can also be observed in the mean deviation from the plane of the atoms of the chelating rings which in $\mathbf{1 1}$ is the same in both $\mathrm{V}-\mathrm{O}-\mathrm{C}-\mathrm{C}-\mathrm{C}-\mathrm{N}$ chelating rings $(0.292 \AA)$ while they are different in $\mathbf{1 2}(0.282$ and $0.300 \AA)$.

The H-bonding network is quite complex. Several atoms are involved in $\mathrm{H}$-bonding with the neighbouring solvent molecules and this is described in section ESI-A (Supporting information). The $\mathrm{Na}^{+}$cation interacts strongly with $\mathrm{O}(4)[\mathrm{Na}-\mathrm{O}(4) 2.424(6) \AA]$ and the water molecules (see Table 2).

\section{Infrared Spectra}

A set of selected IR bands for compounds 1-12 are summarised in section ESI-B (Supporting information). The assignments were made based on refs. ${ }^{[15,23,24]}$ and by comparison of the spectra. While the spectrum of $\mathbf{2}$ in the powder and crystalline forms shows only one $v(\mathrm{C}=\mathrm{N})$ strong band at $1633 \mathrm{~cm}^{-1}$, the IR spectrum of $\mathrm{KH}(o \text {-van })_{2}$ en shows two

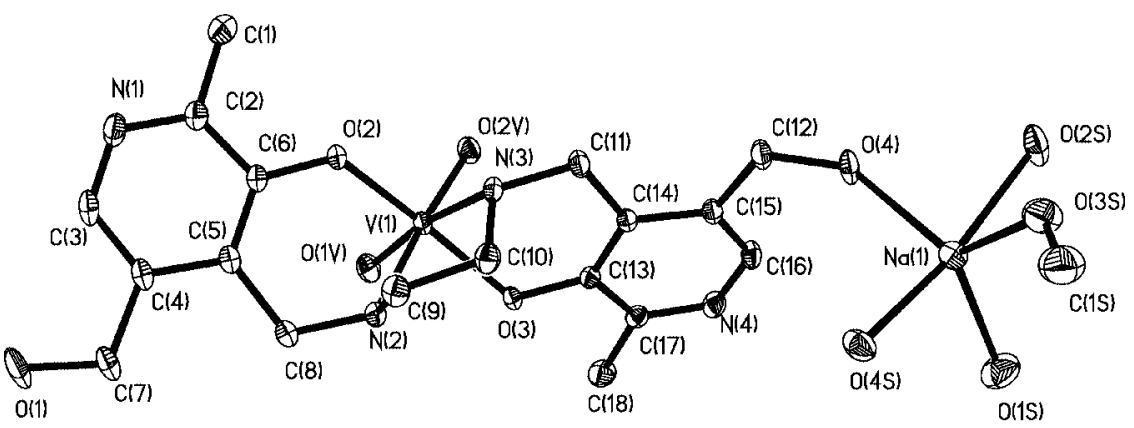

Figure 2. ORTEP diagram of $\mathrm{Na}\left[\mathrm{VO}_{2}\left(\mathrm{Rpyr}_{2} \mathrm{en}\right)\right] \cdot \mathrm{CH}_{3} \mathrm{OH} \cdot 3 \mathrm{H}_{2} \mathrm{O}$ (11) showing the atom labelling scheme; thermal ellipsoids have been drawn at the $30 \%$ probability level 
Table 2. Selected bond lengths $[\AA]$ and angles $\left[{ }^{\circ}\right]$ for $\mathrm{Na}\left[\mathrm{V}^{\mathrm{V}} \mathrm{O}_{2}\left(\mathrm{Rpyr}_{2} \mathrm{en}\right)\right] \cdot \mathrm{CH}_{3} \mathrm{OH} \cdot 3 \mathrm{H}_{2} \mathrm{O}(\mathbf{1 1})$

\begin{tabular}{ll|lc}
\hline \multicolumn{3}{c|}{ Bond lengths } & \multicolumn{2}{c}{ Angles } \\
\hline $\mathrm{V}(1)-\mathrm{O}(1 \mathrm{~V})$ & $1.643(5)$ & $\mathrm{O}(1 \mathrm{~V})-\mathrm{V}(1)-\mathrm{O}(2 \mathrm{~V})$ & $107.4(3)$ \\
$\mathrm{V}(1)-\mathrm{O}(2 \mathrm{~V})$ & $1.662(5)$ & $\mathrm{O}(1 \mathrm{~V})-\mathrm{V}(1)-\mathrm{O}(3)$ & $96.5(2)$ \\
$\mathrm{V}(1)-\mathrm{O}(3)$ & $1.957(4)$ & $\mathrm{O}(2 \mathrm{~V})-\mathrm{V}(1)-\mathrm{O}(3)$ & $96.0(2)$ \\
$\mathrm{V}(1)-\mathrm{O}(2)$ & $1.960(5)$ & $\mathrm{O}(1 \mathrm{~V})-\mathrm{V}(1)-\mathrm{O}(2)$ & $97.4(2)$ \\
$\mathrm{V}(1)-\mathrm{N}(2)$ & $2.284(6)$ & $\mathrm{O}(2 \mathrm{~V})-\mathrm{V}(1)-\mathrm{O}(2)$ & $155.9(2)$ \\
$\mathrm{V}(1)-\mathrm{N}(3)$ & $2.305(6)$ & $\mathrm{O}(3)-\mathrm{V}(1)-\mathrm{O}(2)$ & $88.9(2)$ \\
$\mathrm{O}(3)-\mathrm{C}(13)$ & $1.347(7)$ & $\mathrm{O}(1 \mathrm{~V})-\mathrm{V}(1)-\mathrm{N}(2)$ & $163.8(2)$ \\
$\mathrm{O}(2)-\mathrm{C}(6)$ & $1.354(7)$ & $\mathrm{O}(2 \mathrm{~V})-\mathrm{V}(1)-\mathrm{N}(2)$ & $82.0(2)$ \\
$\mathrm{N}(2)-\mathrm{C}(8)$ & $1.472(8)$ & $\mathrm{O}(3)-\mathrm{V}(1)-\mathrm{N}(2)$ & $79.6(2)$ \\
$\mathrm{N}(3)-\mathrm{C}(11)$ & $1.468(8)$ & $\mathrm{O}(2)-\mathrm{V}(1)-\mathrm{N}(2)$ & $162.8(2)$ \\
$\mathrm{N}(2)-\mathrm{C}(9)$ & $1.464(9)$ & $\mathrm{O}(1 \mathrm{~V})-\mathrm{V}(1)-\mathrm{N}(3)$ & $89.6(2)$ \\
$\mathrm{N}(3)-\mathrm{C}(10)$ & $1.479(9)$ & $\mathrm{O}(2 \mathrm{~V})-\mathrm{V}(1)-\mathrm{N}(3)$ & $78.34(19)$ \\
& & $\mathrm{O}(3)-\mathrm{V}(1)-\mathrm{N}(3)$ & $81.87(19)$ \\
& & $\mathrm{O}(2)-\mathrm{V}(1)-\mathrm{N}(3)$ & $74.2(29)$ \\
\hline
\end{tabular}

\begin{tabular}{lcccc}
\hline \multicolumn{4}{c}{ Bond lengths and angles involving the water molecules } \\
\hline $\mathrm{X} 1-\mathrm{H}-\mathrm{X} 2$ & $d(\mathrm{X} 1-\mathrm{H})$ & $d(\mathrm{H}-\mathrm{X} 2)$ & $d(\mathrm{X} 1-\mathrm{X} 2)$ & angle $(\mathrm{X} 1-\mathrm{H}-\mathrm{X} 2)$ \\
\hline $\mathrm{O} 1-\mathrm{H} 10-\mathrm{O} 2 \mathrm{~S}$ & 0.90 & 2.33 & $2.802(8)$ & 112.3 \\
$\mathrm{~N} 2-\mathrm{H} 2 \mathrm{~N}-\mathrm{O} 4 \mathrm{~S}$ & $1.000(2)$ & $2.196(16)$ & $2.188(8)$ & $171(7)$ \\
$\mathrm{O} 2 \mathrm{~S}-\mathrm{H} 2 \mathrm{SB}-\mathrm{O} 2 \mathrm{~V}$ & $0.900(2)$ & $1.96(2)$ & $2.802(8)$ & $166(9)$ \\
O2S-H2SA-O1 & $0.900(2)$ & $2.02(6)$ & $3.288(9)$ & $145(9)$ \\
N3-H3N-O2S & $1.000(2)$ & $2.39(4)$ & $2.812(8)$ & $149(6)$ \\
O4S-H4SA-N4 & $0.900(2)$ & $1.918(14)$ & $2.868(7)$ & $172(9)$ \\
O4S-H4SB-O3 & $0.900(2)$ & $2.93(4)$ & $154(9)$ \\
\hline
\end{tabular}

strong bands at 1638 and $1617 \mathrm{~cm}^{-1}$. This may be explained by the different $\mathrm{H}$-bonding networks.

The characteristic $v(\mathrm{~V}=\mathrm{O})$ of oxovanadium(IV) complexes appears as a medium-strong band at $960 \mathrm{~cm}^{-1}$ in the IR spectrum of 8 , in agreement with the literature. ${ }^{[17]}$ For the $\mathrm{V}^{\mathrm{IV}} \mathrm{O}$ complexes of the reduced $\mathrm{SB}$, the $v(\mathrm{~V}=\mathrm{O})$ is shifted to lower wavenumbers by ca. $100 \mathrm{~cm}^{-1}$. These low $v(\mathrm{~V}=\mathrm{O})$ values indicate $\mathrm{V}=\mathrm{O} \cdots \mathrm{V}=\mathrm{O}$ interactions and this is in agreement with the magnetic susceptibility measurements (see below). The binding of an $\mathrm{O}_{\text {oxo }}$ atom to an adjacent vanadium atom trans to its vanadyl $\mathrm{O}$ atom lengthens and weakens the bond, thereby lowering the $\mathrm{V}=\mathrm{O}$ stretching frequency.

\section{Electronic Absorption Spectra}

The electronic absorption spectra of bis(salicylaldimines) and their transition metal complexes have been extensively studied. ${ }^{[25-28]}$ All free Schiff bases 1-3 show a broad band centred at ca. $320 \mathrm{~nm}$ due to an $\mathrm{n} \rightarrow \pi^{*}$ transition associated with the azomethine group and another band at around $260 \mathrm{~nm}$ which may arise from a transition involving mainly the $\pi$ molecular orbitals localised on the $\mathrm{C}=\mathrm{N}$ group and/ or the aromatic ring. ${ }^{[26]}$ In the spectra of the reduced SB compounds, the $\mathrm{n} \rightarrow \pi^{*}$ transition is absent as expected and the $260 \mathrm{~nm}$ transition is red-shifted and less intense. Section ESI-C (Supporting information) summarises the UV/Vis data.

Although three (or four) d-d bands can be expected to appear in the spectra of the $\mathrm{V}^{\mathrm{IV}} \mathrm{O}$ complexes in the visible region, they are often overlapping or obscured by strong LMCT bands. The spectra of 8-10 show broad bands in the range $500-600 \mathrm{~nm}$ (band II: $\mathrm{d}_{x y} \rightarrow \mathrm{d}_{x^{2}-y^{2}}$ ) and a shoulder at $600-710 \mathrm{~nm}$ (band I: $\mathrm{d}_{x y} \rightarrow \mathrm{d}_{x z}, \mathrm{~d}_{y z}$ ). ${ }^{[29]}$ Band III $\left(\mathrm{d}_{x y} \rightarrow \mathrm{d}_{z^{2}}\right)$ occurs below $500 \mathrm{~nm}$ and is under much stronger LMCT bands (probably $\mathrm{O}_{\text {phenolate }} \rightarrow$ d orbital).

\section{EPR Spectra}

The X-band EPR spectra of frozen solutions $(77 \mathrm{~K})$ of the vanadium complexes, dissolved in DMSO (except for $\mathbf{8}$ which was in water), were measured and simulated with a computer program by Rockenbauer. ${ }^{[30]}$ The EPR parameters obtained are listed in Table 3. All spectra show a small rhombic distortion which can be observed in the perpendicular lines corresponding to $M_{\mathrm{I}}=7 / 2,5 / 2$ and $3 / 2$, indicating a distorted geometry around the metal centre. Although the additivity rule ${ }^{[31]}$ was developed to allow the determination of the identity of the equatorial donor groups in complexes of square-pyramidal geometry (or octahedral with a weak sixth ligand), it has been successfully applied to structurally distorted molecules. ${ }^{[32,33]}$ In the present $\left[\mathrm{V}^{\mathrm{IV}} \mathrm{O}\right]$ complexes, the EPR parameters fit well with a binding mode involving either two equatorial $\mathrm{N}_{\text {amine }}$ and two $\mathrm{O}_{\text {phenolate }}$ centres or two equatorial $\mathrm{N}_{\text {imine }}$ and two $\mathrm{O}_{\text {phenolate }}$ centres. However, since the contribution of equatorial DMSO ligands to $A_{z}$ is ca. $42 \times 10^{-4} \mathrm{~cm}^{-1}$, i.e. close to that of $\mathrm{N}_{\text {amine, }}{ }^{[15]}$ other binding modes cannot be ruled out.

\section{Magnetic Properties}

The magnetic susceptibilities of the vanadium complexes $\mathbf{8}$ and $\mathbf{9}$ were measured by the Faraday method in the tem- 
Table 3. Spin-Hamiltonian parameters obtained by computer simulation ${ }^{[42]}$

\begin{tabular}{cccc}
\hline & $\mathbf{8}$ & $\mathbf{9}$ & $\mathbf{1 0}$ \\
\hline$g_{x}, A_{x}\left(\times 10^{4} \mathrm{~cm}^{-1}\right)$ & $1.983,45.6$ & $1.982,45.4$ & $1.980,48.5$ \\
$g_{y}, A_{y}\left(\times 10^{4} \mathrm{~cm}^{-1}\right)$ & $1.980,50.5$ & $1.977,50.2$ & $1.977,50.4$ \\
$g_{z}, A_{z}\left(\times 10^{4} \mathrm{~cm}^{-1}\right)$ & $1.960,157.7$ & $1.957,158.2$ & $1.958,158.0$ \\
\hline
\end{tabular}

perature range of 3 to $287 \mathrm{~K}$. Data were corrected for diamagnetic contributions using the Pascal's constants. ${ }^{[34]}$ For both complexes the plot of $1 / \chi_{\mathrm{P}}$ vs. $T$ shows deviations from linearity which can be accounted for by assuming a CurieWeiss law and a temperature-independent paramagnetism (TIP) term. The magnetic susceptibility of compound $\mathbf{8}$ fits well the Curie-Weiss law. A $\mu_{\text {eff }}$ of $1.76 \mu_{\mathrm{B}}$ was obtained at room temperature which is typical for compounds with a spin $1 / 2$, indicating that $\mathbf{8}$ is monomeric. This is in agreement with the $v(\mathrm{~V}=\mathrm{O})$ obtained. Evans ${ }^{[17]}$ also reported a roomtemperature magnetic moment of $1.76 \mu_{\mathrm{B}}$ for $\mathbf{8}$ in aqueous solution at $\mathrm{pH}=8.4$.

Complex 9 shows temperature dependence for the $\mu_{\mathrm{eff}} \mathrm{Val}-$ ues. A smaller $\mu_{\text {eff }}$ value than the theoretical for $S=1 / 2$ was obtained (see section ESI-D of the Supporting information). This low magnetic moment indicates that there are $\mathrm{V}=\mathrm{O} \cdots \mathrm{V}=\mathrm{O}$ interactions which is in agreement with the low $v(\mathrm{~V}=\mathrm{O})$ measured for this complex (see above). Low $\mu_{\mathrm{eff}}$ and $v(\mathrm{~V}=\mathrm{O})$ values were also found for several $\mathrm{sal}_{2}$ entype SB vanadium complexes ${ }^{[35-37]}$ including $\left[\mathrm{V}^{\mathrm{IV}} \mathrm{O}-\right.$ $\left.\left(\operatorname{Rpyr}_{2} \mathrm{en}\right)\right]^{[15]}$

\section{Speciation Studies}

\section{$\left(\mathrm{SO}_{3} \text {-sal }\right)_{2}$ en (3) and $\mathrm{R}\left(\mathrm{SO}_{3} \text {-sal }\right)_{2}$ en (6)}

Compounds $\mathbf{3}$ and $\mathbf{6}$ are water-soluble and their acidbase behaviour was studied by $\mathrm{pH}$ potentiometry and ${ }^{1} \mathrm{H}$ NMR spectroscopy. The protonation constants of $\mathbf{6}$ are listed in Table 4. For the SB 3, both the evaluation of the titration curves and the ${ }^{1} \mathrm{H}$ NMR studies indicate the occurrence of hydrolytic processes. For the reduced SB 6, no hydrolysis could be detected in the whole $\mathrm{pH}$ range. The SB $\mathrm{sal}_{2} \mathrm{en}$ also undergoes hydrolysis in strongly acidic DMSO/ water $[80: 20(\mathrm{w} / \mathrm{w})]$ solutions. ${ }^{[38]}$ In contrast, the SB $N, N^{\prime}$ $o$-phenylenebis(salicylideneimine) is stable under the same conditions at $\mathrm{pH}>2.5$. ${ }^{[39]}$

In order to study the hydrolytic processes of compound 3 , several samples were prepared by dissolving the $\mathrm{SB}\left(\mathrm{SO}_{3}\right.$ sal) $)_{2}$ en and either ${ }^{1} \mathrm{H}$ NMR or $\mathrm{pH}$-potentiometric data were collected and evaluated with the computer programs PSEQUAD $^{[40]}$ and SUPERQUAD ${ }^{[41]}$ respectively. Our objective was to obtain a reasonably quantitative approach for the species which form as the $\mathrm{pH}$ is varied, but not very

Table 4. A) Protonation and formation constants of species $\mathrm{M}_{p} \mathrm{~L}_{q} \mathrm{H}_{r}$ formed in the $\mathrm{V}^{\mathrm{IV}} \mathrm{O}$ and $\mathrm{V}^{\mathrm{V}} \mathrm{O}_{2}-\mathrm{H}_{2} \mathrm{R}\left(\mathrm{SO}_{3} \text {-sal }\right)_{2}$ en systems calculated from the pH-potentiometric data with the PSEQUAD program: $\left.;{ }^{[40]} \mathrm{B}\right)$ protonation and formation constants of species $\left(\mathrm{en}_{p}\left(\mathrm{SO}_{3} \text {-sal }\right)_{q}\left(\mathrm{H}^{+}\right)_{r}\right.$ [the main products formed upon dissolving $\left(\mathrm{SO}_{3} \text {-sal }\right)_{2}$ en in water] obtained from the potentiometric and ${ }^{1} \mathrm{H}$ NMR spectroscopic data (see Figure 3 and Scheme ESI-1 in section ESI-E of Supporting information)

\begin{tabular}{|c|c|c|c|c|c|}
\hline & \multicolumn{2}{|c|}{ A) $\mathrm{R}\left(\mathrm{SO}_{3} \text {-sal }\right)_{2}$ en } & \multicolumn{3}{|c|}{ B) $\left(\mathrm{SO}_{3} \text {-sal }\right)_{2} \mathrm{en}$} \\
\hline & $\log \beta^{[\mathrm{a}]}$ & $\mathrm{p} K_{\mathrm{a}}$ & Composition $^{[\mathrm{c}]}(p, q, r)$ & $\log \beta\left({ }^{1} \mathrm{H} \mathrm{NMR}\right)^{[\mathrm{d}]}$ & $\log \beta$ (potentiometry) $^{[\mathrm{e}]}$ \\
\hline HL & $10.70(9)$ & 10.70 & & & \\
\hline $\mathrm{H}_{2} \mathrm{~L}$ & $19.50(9)$ & 8.80 & $(101)$ & $9.90(7)$ & $9.99^{[42]}$ \\
\hline $\mathrm{H}_{3} \mathrm{~L}$ & $27.03(9)$ & 7.53 & (102) & $16.67(10)$ & $17.18^{[42]}$ \\
\hline \multirow[t]{2}{*}{$\mathrm{H}_{4} \mathrm{~L}$} & $33.11(18)$ & 6.08 & & & \\
\hline & $\log \beta\left(\mathrm{V}^{\mathrm{IV}} \mathrm{O}^{2+}\right)^{[\mathrm{a}]}$ & $\log \beta\left(\mathrm{V}^{\mathrm{V}} \mathrm{O}_{2}{ }^{+}\right)^{[\mathrm{a}]}$ & $(011)$ & $6.72(1)$ & $6.78(2)$ \\
\hline $\mathrm{MLH}_{2}$ & $26.88(21)$ & $45.2(3)$ & (111) & $12.21(3)$ & $12.02(4)$ \\
\hline MLH & - & $39.3(3)$ & (112) & $20.30(2)$ & $20.45(2)$ \\
\hline ML & $18.97(3)$ & $32.45(12)$ & (121) & $12.80(15)$ & \\
\hline $\mathrm{MLH}_{-1}$ & $9.50(12)$ & - & $(122)$ & $22.40(3)$ & $22.42(8)$ \\
\hline Fitting & $5.19 \times 10^{-3[b]}$ & $1.07 \times 10^{-2[\mathrm{~b}]}$ & Fitting & $7.83 \times 10^{-4[\mathrm{f}]}$ & $9.57 \times 10^{-3[\mathrm{~g}]}$ \\
\hline No. of points & 290 & 304 & No. of points & $80(4 \times 20)$ & 373 \\
\hline
\end{tabular}

[a] In order to account for the range of the $\log \beta_{p q r}$ values obtained by $\mathrm{pH}$-potentiometry in the several equilibrium models tested, the standard deviation S.D. is multiplied by 3 and the values are included in brackets. [b] Average of the difference between the experimental and calculated titration curves, expressed as the volume $(\mathrm{mL})$ of titrant. [c] Other stoichiometries $(110,113,120,123$ and 124) were not possible to fit. [d] Ambient temperature (ca. $25^{\circ} \mathrm{C}$ ), ionic strength not fixed. The S.D. values presented are those obtained in the particular model shown. [e] $T=25^{\circ} \mathrm{C}, I=0.20 \mathrm{M} \mathrm{KCl}$. [f] Average of the difference between the experimentally determined and the calculated concentrations of en, $\mathrm{SO}_{3}$-sal, $\mathrm{HSB}$ and $\mathrm{SB}$. Some figures showing the fitting between the calculated and experimental chemical shifts are given in section ESI-E (Supporting information). [g] Average difference between the experimental and calculated titration curves, expressed in $\mathrm{pH}$. Some figures showing the fitting between the calculated and experimental $\mathrm{pH}$-potentiometric curves are given in section ESI-E (Supporting information). 
accurate $\mathrm{p} K$ values. From the ${ }^{1} \mathrm{H}$ NMR spectra, all chemical shift values were assigned and then set as constants which were used to determine all the other protonation and formation constants from the $\mathrm{pH}$ concentration dependence for each species. The $\mathrm{pH}$ dependence of the chemical shifts assigned to the peaks of the free ethylenediamine and aldehyde protons were also used to determine their $\mathrm{p} K$ values with PSEQUAD ${ }^{[40]}$ (see ESI-E). The potentiometric data were treated separately.

The species were expressed as (en $)_{p}\left(\mathrm{SO}_{3}-\mathrm{sal}\right)_{q}\left(\mathrm{H}^{+}\right)_{r}$ and the protonation and formation constants of the main products formed were determined. Table $4 \mathrm{~B}$ contains the protonation and formation constants, section ESI-E (Supporting information) contains information on the calculations and Figure 3 shows a concentration distribution diagram showing the total concentrations of each main compound.

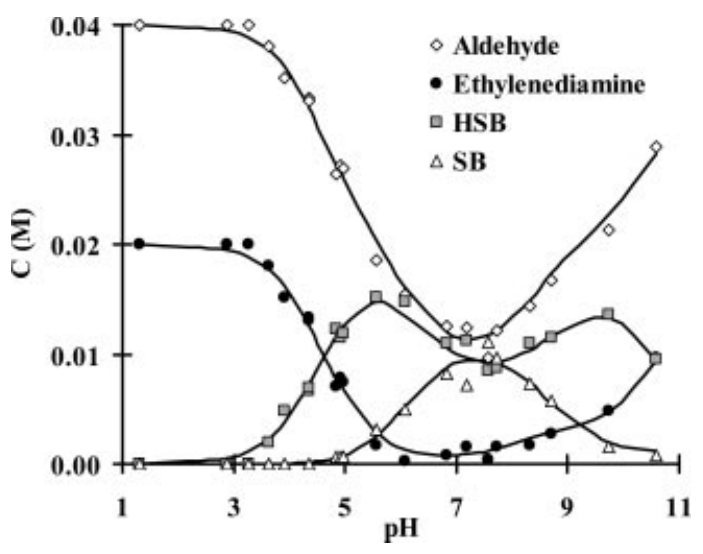

Figure 3. Concentration distribution curves of hydrolytic species formed in solutions containing compound 3 (see Scheme ESI-1 of Supporting information); only the total concentrations of each compound [aldehyde $=\left(\mathrm{SO}_{3}\right.$-sal $) ; \mathrm{HSB}=\left(\mathrm{SO}_{3}\right.$-sal $)$ en, $\mathrm{SB}=\left[\mathrm{SO}_{3^{-}}\right.$ $\left.\mathrm{sal}_{2} \mathrm{en}\right]$ are represented

We can conclude that for SB 3, the hydrolysis is very extensive, much more than for pyr $_{2}$ en and occurs in the whole measurable $\mathrm{pH}$ range. With $\mathrm{pyr}_{2} \mathrm{en}$, hydrolysis was only detected to a small extent at $\mathrm{pH}>7 . .^{[15]}$

\section{Vanadium(IV) Complexes}

Although potentiometric and spectroscopic studies were carried out with SB 3, its extensive hydrolysis did not allow a consistent evaluation of the system. For the corresponding reduced SB 6, the interaction with $\left[\mathrm{V}^{\mathrm{IV}} \mathrm{O}\right]^{2+}$ and $\left[\mathrm{V}^{\mathrm{V}} \mathrm{O}_{2}\right]^{+}$ was studied and the corresponding stability constants are also listed in Table 4. With $\left[\mathrm{V}^{\mathrm{IV}} \mathrm{O}^{2+}\right.$ the $\mathrm{pH}$-metric data were evaluated only up to $\mathrm{pH} \approx 9.5$ since slow processes occur at higher $\mathrm{pH}$ values (oxidation and/or hydrolysis). The species distribution diagram is presented in Figure 4a. The complex formation starts at $\mathrm{pH} \approx 4$ with the formation of the neutral complex $\left[\mathrm{VOLH}_{2}\right]$. The ligand forms quite stable 1:1 complexes with $\left[\mathrm{V}^{\mathrm{IV}} \mathrm{O}\right]^{2+}$ and the stoichiometry $[\mathrm{VOL}]^{2-}$ predominates in the $\mathrm{pH}$ range 4.5-9.0. In the basic $\mathrm{pH}$ range, the process $[\mathrm{VOL}]^{2-} \rightleftarrows\left[\mathrm{VOLH}_{-1}\right]^{3-}+\mathrm{H}^{+}$has a $\mathrm{p} K$ of ca. 9.5 .
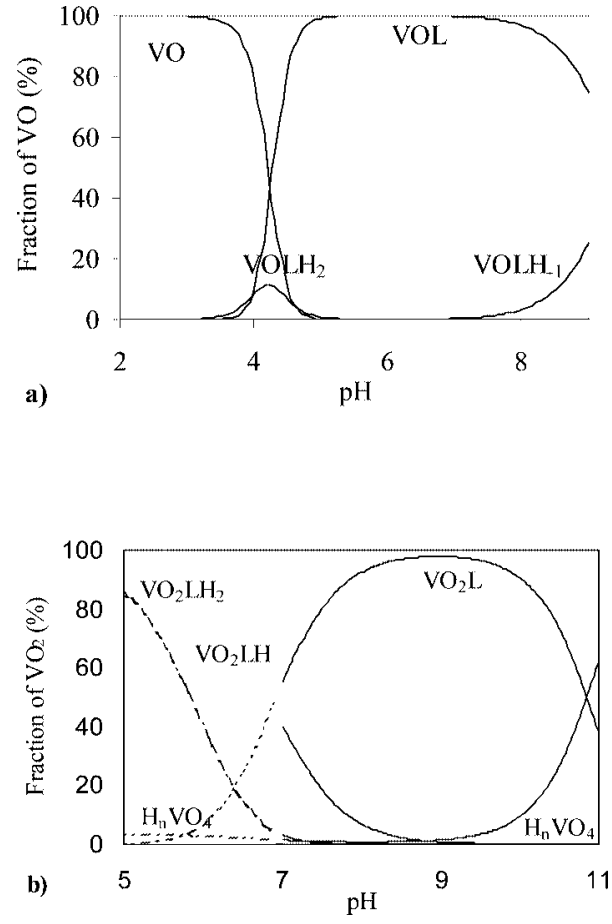

Figure 4. Concentration distribution curves of complexes formed in solutions containing: a) $\left[\mathrm{V}^{\mathrm{IV}} \mathrm{O}\right]^{2+}$ and $\mathrm{R}\left(\mathrm{SO}_{3} \text {-sal }\right)_{2}$ en with $C_{\mathrm{VO}}=$ $1.0 \mathrm{mM}$ and $\mathrm{L} / \mathrm{M}=2$; b) $\left[\mathrm{V}^{\mathrm{V}} \mathrm{O}_{2}\right]^{+}$and $\mathrm{R}\left(\mathrm{SO}_{3} \text {-sal }\right)_{2}$ en with $C_{\mathrm{V}}=$ $3.0 \mathrm{mM}$ and $\mathrm{L} / \mathrm{M}=2$, calculated using the stability constants listed in Table 4; the dashed lines indicate that the curves only represent an approximate estimation of the relative concentrations (see text)

Figure 5 shows the high-field region of the X-band EPR spectra of "frozen" solutions containing $\left[\mathrm{V}^{\mathrm{IV}} \mathrm{O}\right]^{2+}$ and $\mathbf{6}$ at several different $\mathrm{pH}$ values. The EPR parameters were obtained by computer simulation ${ }^{[30]}$ of the EPR spectra. At $\mathrm{pH}<4$ the only species present is the (aqua)vanadyl ion. At $\mathrm{pH}>4$ two new species form. [VOLH $\left.{ }_{2}\right]$ only forms in

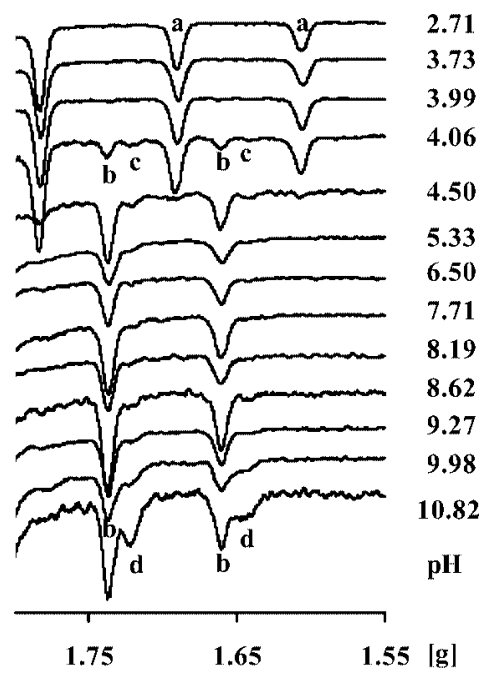

Figure 5. High-field region of the EPR spectra $(77 \mathrm{~K})$ of frozen solutions containing $\left[\mathrm{V}^{\mathrm{IV}} \mathrm{O}\right]^{2+}$ and $\mathrm{R}\left(\mathrm{SO}_{3} \text {-sal }\right)_{2}$ en at several $\mathrm{pH}$ values with $\mathrm{L} / \mathrm{M}=1$ and $C_{\mathrm{VO}} \approx 0.004 \mathrm{M}$; four main components can be detected a: $\left[\mathrm{VO}\left(\mathrm{H}_{2} \mathrm{O}\right)_{5}\right]$, b: VOL, c: $\mathrm{VOLH}_{2}$ and d: $\mathrm{VOLH}_{-1}$ (charges omitted) 
low concentration (ca. 10\%) and its EPR parameters are $g_{z}$ $\approx 1.945$ and $A_{z} \approx 168 \times 10^{-4} \mathrm{~cm}^{-1}$. The additivity rule ${ }^{[31]}$ applied to bidentate coordination of the ligand, i.e. through equatorial binding of $\mathrm{O}_{\text {phenolate, }} \mathrm{N}_{\text {amine }}$ and two $\mathrm{H}_{2} \mathrm{O}$ groups yields $A_{z}^{\text {estim }}=170 \times 10^{-4} \mathrm{~cm}^{-1}$, so this is probably the binding mode of $\mathrm{VOLH}_{2}$.

For VOL, the EPR parameters ${ }^{[30]} g_{x}, g_{y}$ and $g_{z}$ are 1.982 , 1.976 and 1.957, respectively, and $A_{x}, A_{y}$ and $A_{z}$ are 52, 50 and $159 \times 10^{-4} \mathrm{~cm}^{-1}$. This indicates an equatorial binding mode involving two $\mathrm{O}_{\text {phenolate }}$ and two $\mathrm{N}_{\text {amine }}$ centres, $A_{z}{ }^{\text {estim }}=157 \times 10^{-4} \mathrm{~cm}^{-1}$. In all the EPR spectra above $\mathrm{pH}$ $\approx 4$ a second minor component is present which probably corresponds to a binding mode of two equatorial $\mathrm{O}_{\text {phenolate }}$ centres, one equatorial $\mathrm{N}_{\text {amine }}$ and one equatorial $\mathrm{O}_{\text {water }}$ centre as well as one axial $\mathrm{N}_{\text {amine }}$ centre, $A_{z}$ estim $=$ $164 \times 10^{-4} \mathrm{~cm}^{-1}$. Therefore, equilibrium between cis/trans isomers apparently occurs as observed in the $\mathrm{V}^{\mathrm{IV}} \mathrm{O}_{-}$ $\mathrm{Rpyr}_{2}$ en system. ${ }^{[15]}$ However, in the present system the position of this equilibrium is shifted to the trans isomer (which presumably contains the $\mathrm{H}_{2} \mathrm{O}$ ligand trans to the $\mathrm{O}_{\text {oxo }}$ atom) and the EPR spectra could be satisfactorily simulated assuming some rhombic distortion from a square-pyramidal structure.

Above $\mathrm{pH} \approx 9$ a new signal could be observed in the EPR spectra corresponding to the hydroxo complex
[VOLH ${ }_{-1}$ ]. The corresponding $g_{z}$ and $A_{z}$ parameters are ca. 1.948 and ca. $162 \times 10^{-4} \mathrm{~cm}^{-1}$, respectively. Possible equatorial binding modes are by two $\mathrm{N}_{\text {amine, }}$ an $\mathrm{O}_{\text {phenolate }}$ and an $\mathrm{OH}^{-}$with $A_{z}^{\text {estim }}=158 \times 10^{-4} \mathrm{~cm}^{-1}$ and by two $\mathrm{O}_{\text {phenolate }}$ centres, an $\mathrm{N}_{\text {amine }}$ and an $\mathrm{OH}^{-}$with $A_{z}^{\text {estim }}=$ $156 \times 10^{-4} \mathrm{~cm}^{-1}$. The binding mode for $\left[\mathrm{VOLH}_{-1}\right]$ probably corresponds to the first case.

The visible absorption spectra for this system confirm the speciation model obtained by $\mathrm{pH}$ potentiometry. At $\mathrm{pH}$ $=3.1$ the spectrum corresponds to the spectrum of $\mathrm{V}^{\mathrm{I}-}$ $\left.{ }^{\mathrm{O}}\left(\mathrm{H}_{2} \mathrm{O}\right)_{5}\right]^{2+}$. In the $\mathrm{pH}$ range 5-7 the spectra do not change and the $\mathrm{d}-\mathrm{d}$ bands at $\lambda_{\max }=535 \mathrm{~nm}(\varepsilon=112$ $\left.\mathrm{M}^{-1} \mathrm{~m}^{-1}\right)$ and $840 \mathrm{~nm}\left(\varepsilon \approx 50 \mathrm{M}^{-1} \mathrm{~m}^{-1}\right)$ correspond to VOL. Below $400 \mathrm{~nm}$ there is a charge-transfer band probably due to transitions between $\mathrm{O}_{\text {phenolate }}$ and empty $\mathrm{d}$ orbitals on the $\mathrm{V}$ atom.

\section{Vanadium(v) Complexes}

The interaction between $\mathrm{R}\left(\mathrm{SO}_{3} \text {-sal }\right)_{2}$ en and $\mathrm{V}^{\mathrm{V}}$ was studied by $\mathrm{pH}$ potentiometry and ${ }^{1} \mathrm{H}$ and ${ }^{51} \mathrm{~V}$ NMR spectroscopy. The species distribution diagram is shown in Figure 4B and Table 4 contains the complex formation constants. The $\mathrm{pH}$-potentiometric titrations were carried out between $\mathrm{pH}=11.5$ and 2 but due to the slow formation of a small percentage of decavanadate species below $\mathrm{pH} \approx 5$,
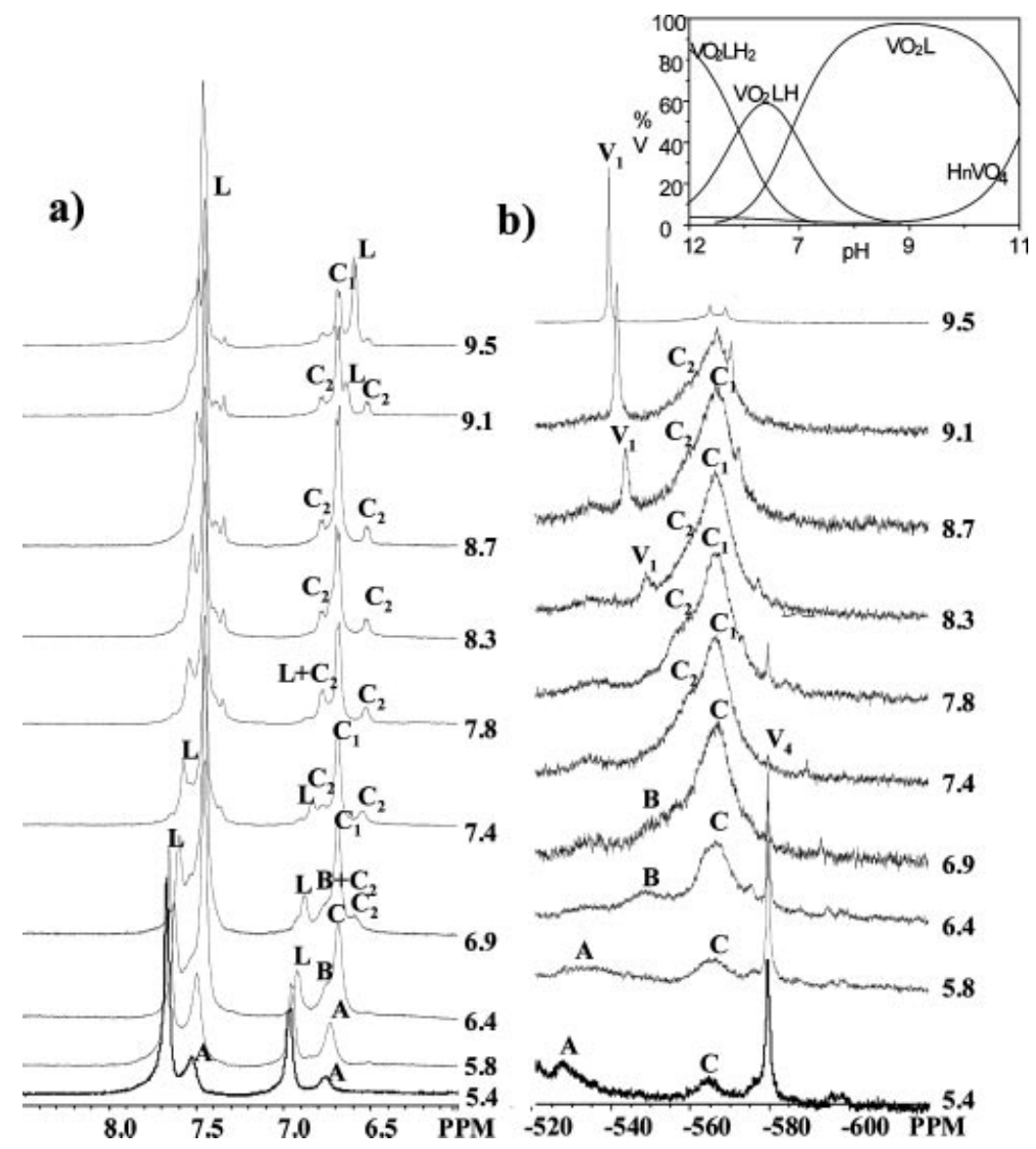

Figure 6. NMR spectra at different $\mathrm{pH}$ values of $\mathrm{D}_{2} \mathrm{O}$ of solutions containing $\mathrm{V}^{\mathrm{V}}$ and $\mathrm{R}\left(\mathrm{SO}_{3} \text {-sal }\right)_{2}$ en with $C_{\mathrm{V}}=20 \mathrm{mM}$ and $\mathrm{L}$ : $\mathrm{M} \approx 1.1$; a) aromatic region $(8.5<\delta<6.0 \mathrm{ppm})$ of the ${ }^{1} \mathrm{H}$ NMR spectra and b) ${ }^{51} \mathrm{~V}$ NMR spectra; $\mathbf{C}=\mathbf{C}_{\mathbf{1}}+\mathbf{C}_{\mathbf{2}}$; inset: concentration distribution curves for the conditions used in the NMR experiments 
the model that showed the best fitting was obtained by considering only data at $\mathrm{pH}>5.7$. The complexes formed between $\mathrm{V}^{\mathrm{V}}$ and $\mathbf{6}$ are quite stable and correspond to a $1: 1$ stoichiometry in several protonation states. For an L/M ratio of 2 (and $C_{\mathrm{V}}=3 \mathrm{mM}$ ), some hydrolysis occurs only above $\mathrm{pH} \approx 10$ with the formation of $\left[\mathrm{HVO}_{4}\right]^{2-}$ and $\left[\mathrm{VO}_{4}\right]$ ${ }^{3-}$ (see Figure 4B).

The ${ }^{51} \mathrm{~V}$ NMR spectra (Figure 6B) are quite complex, showing signals corresponding to a variety of $\mathrm{V}^{\mathrm{V}}$ species including monovanadate $\left(\mathrm{V}_{1}\right)$, its oligomers $\left(\mathrm{V}_{2}\right.$ and $\left.\mathrm{V}_{4}\right)$ and $\mathrm{V}^{\mathrm{V}}$-ligand complexes. Although in the potentiometric studies, decavanadate is formed only below $\mathrm{pH} \approx 5$, in these ${ }^{51} \mathrm{~V}$ NMR studies weak decavanadate signals were detected even at $\mathrm{pH} \approx 9$ (data not shown). Nevertheless, the spectraclearly show complex formation between ligand $\mathbf{6}$ and $\left[\mathrm{VO}_{2}\right]^{+}$, e.g. species A, B, $\mathbf{C}_{1}$ and $\mathbf{C}_{2}$ in Figure 6B. These resonances are broad due to quadrupolar relaxation and the asymmetric coordination environment of the $\mathrm{V}^{\mathrm{V}} \cdot{ }^{43]}$

The assignment of these ${ }^{51} \mathrm{~V}$ NMR signals was done taking into account the respective chemical shift values and peak areas (the peak areas were determined with program NUTS $^{[44]}$ after deconvolution of the signals) and by comparison with the speciation diagram of Figure 4b. The resonance $\mathbf{C}_{\mathbf{1}}(\delta \approx-565 \mathrm{ppm})$, observed above $\mathrm{pH} \approx 5$, corresponds to the $\alpha$-cis- $-\mathrm{VO}_{2} \mathrm{~L}$ complex (see Scheme 2) which predominates between $\mathrm{pH} \approx 7$ and 9 , and the $\mathbf{C}_{2}$ signal $(\delta$ $\approx-562 \mathrm{ppm}$ ) of lower intensity appears clearly as a shoulder on signal $\mathbf{C}_{\mathbf{1}}$ above $\mathrm{pH} \approx 7$. This can be assigned to the $\beta$-cis- $\mathrm{VO}_{2} \mathrm{~L}$ isomer. The ${ }^{51} \mathrm{~V}$ NMR shifts of these resonances are in agreement with a binding mode involving $\mathrm{N}_{2} \mathrm{O}_{2}{ }^{[43]}$ and with previous data obtained with the $\mathrm{V}^{\mathrm{V}} \mathrm{O}_{2}-$ $\mathrm{Rpyr}_{2}$ en system. ${ }^{[15]} \mathrm{A}$ low-intensity, broad resonance $\mathbf{B}(\delta$ $\approx-550 \mathrm{ppm}$ ) appears at $\mathrm{pH} \approx 6.4-6.9$ and can be assigned to a $\mathrm{VO}_{2} \mathrm{LH}$ species where the monoprotonated ligand coordination is probably tridentate. Several isomers may coexist since the ligand can coordinate through one or two of the $\mathrm{N}_{\text {amine }}$ and $\mathrm{O}_{\text {phenolate }}$ atoms, this being a plausible explanation for the broadness of the peak. Resonance $\mathbf{A}(\delta \approx-$ $530 \mathrm{ppm}$ ), with a maximum intensity at $\mathrm{pH} \approx 5.4$, is practically absent at $\mathrm{pH}=6.4$. It should correspond to a $\mathrm{VO}_{2} \mathrm{LH}_{2}$ complex, in which the coordination of the diprotonated ligand is probably bidentate. Again several isomers may coexist. Between $\mathrm{pH}=6.9$ and 8.2 a weak broad signal can be observed at $\delta \approx-535 \mathrm{ppm}$ but its assignment is not straightforward. It is probably an isomer of complex $\mathbf{B}$ since it appears in the same $\mathrm{pH}$ range (see Figure $6 \mathrm{~b}$ ). The ${ }^{51} \mathrm{~V}$ shift trend observed as the complex is protonated is in agreement with a decreasing ligand coordination number. ${ }^{[45,46]}$

${ }^{51} \mathrm{~V}$ and ${ }^{1} \mathrm{H}$ NMR studies for the $\mathrm{V}^{\mathrm{V}} \mathrm{O}_{2}-\mathrm{Rpyr}_{2}$ en system have shown the existence of equilibria in solution between structural isomers of the $\alpha$ - and $\beta$-cis-type (see Scheme 2). ${ }^{[15]}$ While the $\alpha$-cis isomer is symmetric, in the $\beta$ cis isomer the protons of the two half-molecules are not equivalent, with peaks appearing at different chemical shifts for each half-molecule. Complex 11, with the molecular structure depicted in Figure 2, corresponds to an $\alpha$-cis isomer with $\mathrm{V}^{\mathrm{V}} \mathrm{O}_{2} \mathrm{~L}$ stoichiometry. In aqueous solution its ${ }^{51} \mathrm{~V}$ NMR chemical shift is at $\delta \approx-563 \mathrm{ppm}$ which is close to the value for species $\mathbf{C}_{\mathbf{1}}$ (Figure 6b). Although the ${ }^{51} \mathrm{~V}$ NMR spectra for the present system are not as clear as for the $\mathrm{V}^{\mathrm{V}} \mathrm{O}_{2}-\mathrm{Rpyr}_{2}$ en system, they also display an $\alpha$-/ $/ \beta$-cis isomeric equilibrium: the ${ }^{51} \mathrm{~V}$ NMR signal for species $\mathbf{C}_{\mathbf{1}}$ shows a shoulder at higher frequency (assigned to $\mathbf{C}_{\mathbf{2}}$ in Figure $6 \mathrm{~b}$ ) but the signal overlap due to the proximity of the chemical shifts makes quantification of the equilibrium difficult. However, in the ${ }^{1} \mathrm{H}$ NMR spectra (Figure 6a), the presence of the equilibrium is particularly clear for the aromatic proton signals, e.g.at $\mathrm{pH}=7.4-9.5$, where $\mathrm{VO}_{2} \mathrm{~L}\left(\mathbf{C}_{\mathbf{1}}\right.$ and $\mathbf{C}_{2}$ ) is the only stoichiometry present, three separate ${ }^{1} \mathrm{H}$ NMR resonances can be observed (besides the one corresponding to the excess of free ligand in solution, L). One corresponds to $\mathbf{C}_{\mathbf{1}}$, the $\alpha$-cis isomer, and the other two to $\mathbf{C}_{\mathbf{2}}$, the $\beta$-cis isomer. Thus, as in the $\mathrm{V}^{\mathrm{V}} \mathrm{O}_{2}-\mathrm{Rpyr}_{2}$ en system, ${ }^{[15]}$ while in the $\alpha$-cis complex the protons of each halfmolecule are equivalent, in the $\beta$-cis complex they give rise to two separate signals. Deconvolution of the ${ }^{1} \mathrm{H}$ NMR peaks gave a rough estimate of the ratio between the $\alpha$-cis and $\beta$-cis isomers of ca. 80:20 at $\mathrm{pH}=7.8$ which increases at lower $\mathrm{pH}$. The very low percentage of the $\mathbf{C}_{2}$ isomer precludes observation of its ${ }^{51} \mathrm{~V}$ NMR resonance at $\mathrm{pH}<7.4$ (upon formation of complexes with other stoichiometries) but at higher $\mathrm{pH}$ it is detectable. The small percentage of the $\beta$-cis species might be due to repulsion between the negative $\mathrm{SO}_{3}^{-}$groups which in the $\beta$-cis complex are closer in space. At $\mathrm{pH}=6.9$ and lower, the broad ${ }^{1} \mathrm{H}$ resonances of the protonated $\mathbf{B}$ and $\mathbf{A}$ forms can be observed. Thus, in the present case, slow exchange conditions on the NMR time scale prevail, not only between the two isomers of $\left[\mathrm{VO}_{2} \mathrm{~L}\right]$ and $\mathrm{L}$ but also with $\left[\mathrm{VO}_{2} \mathrm{LH}\right]$ and $\left[\mathrm{VO}_{2} \mathrm{LH}_{2}\right]$ because, in this case, ligand protonation causes a change of $\mathrm{V}^{\mathrm{V}}$ coordination which was not the case for $\mathrm{V}^{\mathrm{V}} \mathrm{O}_{2}-\mathrm{Rpyr}_{2}$ en in which ligand protonation only resulted in ${ }^{1} \mathrm{H}$ and ${ }^{51} \mathrm{~V}$ chemical shift changes. ${ }^{[15]}$

\section{Conclusions}

The SB ligands sal ${ }_{2} \mathrm{en},(o \text {-van })_{2} \mathrm{en},\left(\mathrm{SO}_{3} \text {-sal }\right)_{2} \mathrm{en}$ and their reduced derivatives $\mathrm{H}_{2} \mathrm{Rsal}_{2} \mathrm{en}, \mathrm{H}_{2} \mathrm{R}(o \text {-van })_{2}$ en and $\mathrm{H}_{2} \mathrm{R}\left(\mathrm{SO}_{3} \text {-sal }\right)_{2}$ en were synthesised in good yields and the structures of $\mathrm{H}_{2}(o \text {-van })_{2}$ en and $\mathrm{KH}(o \text {-van })_{2} \mathrm{en} \cdot 2 \mathrm{H}_{2} \mathrm{O}$ were determined by X-ray diffraction. As expected, the Schiff bases are more susceptible to hydrolysis than the corresponding reduced $\mathrm{SB}$ and ${ }^{1} \mathrm{H}$ NMR studies in aqueous solutions of $\left(\mathrm{SO}_{3} \text {-sal }\right)_{2}$ en indicated the presence of several hydrolysis products, namely the "half SB", the free ethylenediamine and the free $\mathrm{SO}_{3}$-salicylaldehyde.

For the present set of ligands, there is strong IR and magnetic susceptibility evidence that the Schiff base $\mathrm{V}^{\mathrm{IV}} \mathrm{O}$ complexes form monomeric structures in the solid state and that the corresponding reduced Schiff-base complexes form structures with $\mathrm{V}=\mathrm{O} \cdots \mathrm{V}=\mathrm{O}$-type interactions. The potentiometric and spectroscopic studies demonstrate the high affinity of the reduced $\mathrm{SB} \mathrm{R}\left(\mathrm{SO}_{3}-\mathrm{sal}\right)_{2}$ en for $\left[\mathrm{V}^{\mathrm{IV}} \mathrm{O}\right]^{2+}$ and $\left[\mathrm{V}^{\mathrm{V}} \mathrm{O}_{2}\right]^{+}$. The ligand forms stable 1:1 complexes with vanadium in both oxidation states and for the predominant stoi- 
chiometries in solution, $\mathrm{ML}\left(\mathrm{M}=\left[\mathrm{V}^{\mathrm{IV}} \mathrm{O}\right]^{2+}\right.$ and $\left.\left[\mathrm{V}^{\mathrm{V}} \mathrm{O}_{2}\right]^{+}\right)$, there is considerable evidence that there are two types of isomers.

The X-ray diffraction characterisation of both $\left[\mathrm{V}^{\mathrm{V}} \mathrm{O}_{2}\left(\mathrm{HRpyr}_{2} \mathrm{en}\right)\right]^{[15]}$ and $\mathrm{Na}^{+}\left[\mathrm{V}^{\mathrm{V}} \mathrm{O}_{2}\left(\mathrm{Rpyr}_{2} \mathrm{en}\right)\right]^{-}$(11) confirmed the formation of $\mathrm{V}^{\mathrm{V}} \mathrm{O}_{2}-\mathrm{Rpyr}_{2}$ en complexes with different degrees of protonation at the $\mathrm{N}$-pyridine sites, thus confirming some data from the earlier report for this system. ${ }^{[15]}$

Complexes 8, 9 and $\left[\mathrm{V}^{\mathrm{IV}} \mathrm{O}\left(\mathrm{Rpyr}_{2} \mathrm{en}\right)\right]$ were tested for toxicity and insulin-mimetic effects in vitro through studies involving mice fibroblasts. ${ }^{[16]}$ When compared with other compounds tested, $\left[\mathrm{V}^{\mathrm{IV}} \mathrm{O}\left(\mathrm{Rpyr}_{2} \mathrm{en}\right)\right]$ showed relatively low toxicity and complex $\mathbf{8}$ showed high efficiency in promoting glucose uptake into cells as well as high aqueous solubility. All these characteristics might be important factors for the therapeutic action of the vanadium complexes.

\section{Experimental Section}

\section{Preparation of Ligands and Complexes}

Synthesis of the Schiff Bases and Reduced Schiff Bases: The Schiffbase ligands were prepared according to literature procedures ${ }^{[47]}$ by reaction of the $o$-hydroxyaldehyde with ethylenediamine $(2: 1)$ in methanol, except for 3 in which the solvent was water. All compounds were characterised by elemental analysis, mass spectrometry and ${ }^{1} \mathrm{H}$ NMR spectroscopy.

sal ${ }_{2}$ en (1): Yield: $0.77 \mathrm{~g}, 95 \%$. $\mathrm{C}_{16} \mathrm{H}_{16} \mathrm{~N}_{2} \mathrm{O}_{2}$ (268.32): calcd. C 71.62, $\mathrm{H}$ 6.01, N 10.44; found $\mathrm{C} 71.6, \mathrm{H} 6.0, \mathrm{~N} 10.5$. MS: $\mathrm{m} / \mathrm{z}=268$ $[\mathrm{M}]^{+} .{ }^{1} \mathrm{H}$ NMR $\left(500 \mathrm{MHz}, \mathrm{CDCl}_{3} 25^{\circ} \mathrm{C}\right): \delta=3.95(\mathrm{~s}, 4 \mathrm{H}$, $\left.-\mathrm{CH}_{2} \mathrm{CH}_{2}-\right), 7.2\left(\mathrm{~m}, 8 \mathrm{H}, \mathrm{CH}_{\text {aromatic }}\right), 8.36(\mathrm{~s}, 2 \mathrm{H}, \mathrm{CH}=\mathrm{N}) \mathrm{ppm}$.

(o-van) ${ }_{2}$ en (2): Yield: $0.89 \mathrm{~g}, 76 \% . \mathrm{C}_{18} \mathrm{H}_{20} \mathrm{~N}_{2} \mathrm{O}_{4}$ (328.37): calcd. C 65.84, H 6.14, N 8.53; found C 65.8, H 6.1, N 8.5. MS: $m / z=228$ $[\mathrm{M}]^{+} .{ }^{1} \mathrm{H} \mathrm{NMR}\left(500 \mathrm{MHz}, \mathrm{CDCl}_{3} 25^{\circ} \mathrm{C}\right): \delta=3.89\left(\mathrm{~s}, 6 \mathrm{H}, \mathrm{CH}_{3}-\right.$ $\mathrm{O}), 3.97$ (s, $\left.4 \mathrm{H},-\mathrm{CH}_{2} \mathrm{CH}_{2}-\right), 6.8\left(\mathrm{~m}, 6 \mathrm{H}, \mathrm{CH}_{\text {aromatic }}\right), 8.33$ (s, 2 $\mathrm{H}, \mathrm{CH}=\mathrm{N}) \mathrm{ppm}$.

Both the filtrate and the washings were kept at room temperature for several weeks and yellow crystals of two different types were collected and characterised by X-ray diffraction. Crystals of $\mathbf{2 A}$ and $\mathbf{2 B}$ were obtained from the washings and filtrates from the synthesis of the Schiff base, respectively. The source of the $\mathrm{K}^{+}$ion was the $\mathrm{KOH}$ solution used to increase the $\mathrm{pH}$ from 4 to ca. 7 .

$\left(\mathbf{S O}_{3} \text {-sal }\right)_{2}$ en (3): The Schiff base was prepared according to a literature procedure. ${ }^{[48]}$ Yield: $1.2 \mathrm{~g}, 87 \% . \mathrm{C}_{16} \mathrm{H}_{14} \mathrm{~N}_{2} \mathrm{Na}_{2} \mathrm{O}_{8} \mathrm{~S}_{2}$ (472.40): calcd. C 40.68, H 2.99, N 5.93, S 13.57; found C 40.7, H 3.0, N 5.9, S 13.4 .

Rsal $_{2}$ en (4): To a solution of the SB $1(0.61 \mathrm{~g}, 2.27 \mathrm{mmol})$ in dichloromethane $(10 \mathrm{~mL})$ at ca. $0{ }^{\circ} \mathrm{C}$ was added a methanolic solution of $\mathrm{NaBH}_{4}(0.076 \mathrm{~g}, 2.0 \mathrm{mmol}, 5 \mathrm{~mL}$ containing some drops of concd. $\mathrm{KOH}$ solution. The $\mathrm{pH}$ was set to 6 and the solution stirred for several hours until the yellow colour had disappeared. The solvent was evaporated to dryness and water $(10 \mathrm{~mL})$ was added to the residue. The $\mathrm{pH}$ was set to $4-5$ by addition of $3 \mathrm{~m} \mathrm{HCl}$. The white solid was filtered, washed with cold water, ethanol and diethyl ether and dried under vacuum. Yield: $0.38 \mathrm{~g}, 61 \% . \mathrm{C}_{16} \mathrm{H}_{20} \mathrm{~N}_{2} \mathrm{O}_{2}$ (272.35): calcd. C 70.56, H 7.40, N 10.29; found C 70.8, H 7.0, N 10.4. MS: $m / z=273[\mathrm{M}]^{+} .{ }^{1} \mathrm{H} \mathrm{NMR}\left(500 \mathrm{MHz}, \mathrm{CDCl}_{3} 25^{\circ} \mathrm{C}\right): \delta=2.85(\mathrm{~s}, 4$ $\left.\mathrm{H},-\mathrm{CH}_{2} \mathrm{CH}_{2}-\right), 4.00\left(\mathrm{~s}, 4 \mathrm{H}, \mathrm{CH}_{2} \mathrm{NH}\right), 7.0\left(\mathrm{~m}, 8 \mathrm{H}, \mathrm{CH}_{\text {aromatic }}\right)$ ppm.
$\mathbf{R}(\boldsymbol{o} \text {-van })_{2}$ en (5): The procedure was similar to the one used for 4 . Yield: $0.57 \mathrm{~g}, 75 \%$. $\mathrm{C}_{18} \mathrm{H}_{24} \mathrm{~N}_{2} \mathrm{O}_{4} \cdot 0.2 \mathrm{MeOH}$ (459.49): calcd. $\mathrm{C} 64.52$, $\mathrm{H}$ 7.38, N 8.27; found $\mathrm{C}$ 64.6, $\mathrm{H}$ 7.5, N 8.1. MS: $\mathrm{m} / \mathrm{z}=333[\mathrm{M}]^{+}$. ${ }^{1} \mathrm{H}$ NMR $\left(500 \mathrm{MHz}, \mathrm{CDCl}_{3} 25^{\circ} \mathrm{C}\right): \delta=2.82\left(\mathrm{~s}, 4 \mathrm{H},-\mathrm{CH}_{2} \mathrm{CH}_{2}-\right.$ ), $3.87\left(\mathrm{~s}, 6 \mathrm{H}, \mathrm{CH}_{3}-\mathrm{O}\right), 3.99\left(\mathrm{~s}, 4 \mathrm{H}, \mathrm{CH}_{2} \mathrm{NH}\right), 6.7(\mathrm{~m}, 6 \mathrm{H}$, $\left.\mathrm{CH}_{\text {aromatic }}\right) \mathrm{ppm}$.

$\mathbf{R}\left(\mathbf{S O}_{3} \text {-sal }\right)_{2}$ en (6): The procedure was similar to the one for $\mathbf{4}$ but the solvent used was water. Yield: $0.77 \mathrm{~g}, \quad 88.0 \%$. $\mathrm{C}_{16} \mathrm{H}_{20} \mathrm{~N}_{2} \mathrm{O}_{8} \mathrm{~S}_{2} \cdot 1.5 \mathrm{H}_{2} \mathrm{O}$ (459.49): calcd. C 41.82, H 5.05, N 6.10, $\mathrm{S}$ 13.95; found $\mathrm{C} 41.7, \mathrm{H} 5.1, \mathrm{~N} 6.0, \mathrm{~S} 14.3 .{ }^{1} \mathrm{H}$ NMR $(500 \mathrm{MHz}$, $\left.\mathrm{D}_{2} \mathrm{O}, \mathrm{pH} \approx 5.7,25^{\circ} \mathrm{C}\right): \delta=3.35\left(\mathrm{~s}, 4 \mathrm{H},-\mathrm{CH}_{2} \mathrm{CH}_{2}-\right), 4.23(\mathrm{~s}, 4 \mathrm{H}$, $\mathrm{CH}_{2} \mathrm{NH}$ ), 6.97 (d, $\left.2 \mathrm{H}, \mathrm{C} H_{\text {aromatic }}\right), 7.67$ (s, $\left.4 \mathrm{H}, \mathrm{CH}_{\text {aromatic }}\right)$ ppm.

$\mathbf{R p y r}_{2}$ en (7): The compound was prepared according to a literature procedure. ${ }^{[15]}$ Yield: $0.83 \mathrm{~g}, 60 \% . \mathrm{C}_{18} \mathrm{H}_{26} \mathrm{~N}_{4} \mathrm{O}_{4}$ (362.43): calcd. C 59.65, H 7.23, N 15.35; found C 59.5, H 7.3, N 15.4. ${ }^{1} \mathrm{H}$ NMR $\left(500 \mathrm{MHz}, \mathrm{D}_{2} \mathrm{O}, \mathrm{pH} \approx 4.8,25^{\circ} \mathrm{C}\right): \delta=2.41\left(\mathrm{~s}, 6 \mathrm{H}, \mathrm{CH}_{3}\right), 3.35(\mathrm{~s}$, $\left.4 \mathrm{H},-\mathrm{CH}_{2} \mathrm{CH}_{2}-\right), 4.35$ (s, $\left.4 \mathrm{H}, \mathrm{CH}_{2} \mathrm{NH}\right), 4.63\left(\mathrm{~s}, 4 \mathrm{H}, \mathrm{CH}_{2} \mathrm{O}\right), 7.62$ (s, $2 \mathrm{H}, \mathrm{C} H_{\text {aromatic }}$ ) ppm.

Synthesis of the Vanadium Complexes: All reactions with the $\mathrm{V}^{\mathrm{IV}} \mathrm{O}$ complexes were carried out under nitrogen.

$\mathbf{C s}_{2}\left[\mathbf{V}^{\mathrm{IV}} \mathbf{O}\left\{\left(\mathbf{S O}_{3} \text {-sal }\right)_{2} \mathbf{e n}\right\}\right]$ (8): The synthesis followed a literature procedure. ${ }^{[17]}$ A pink complex was obtained. Yield: $93 \%$. $\mathrm{C}_{16} \mathrm{H}_{12} \mathrm{~N}_{2} \mathrm{O}_{9} \mathrm{~S}_{2} \mathrm{VCs}_{2} \cdot 0.5 \mathrm{H}_{2} \mathrm{O}$ \{formulation: $\mathrm{Cs}_{2}\left[\mathrm{~V}^{\mathrm{IV}} \mathrm{O}\left\{\left(\mathrm{SO}_{3}{ }^{-\mathrm{sal}}\right)_{2^{-}}\right.\right.$ en $\left.\}]\left(\mathrm{H}_{2} \mathrm{O}\right)_{0.5}\right\}$ (766.16): calcd. C 25.08, H 1.71, N 3.66, S 8.37; found $\mathrm{C} 25.2, \mathrm{H} 2.0, \mathrm{~N} 3.6, \mathrm{~S} 8.4$.

[V ${ }^{\mathbf{I V}} \mathbf{O}\left(\right.$ Rsal $\left.\left._{2} \mathbf{e n}\right)\right]$ (9): Compound 4 (0.27g, $\left.1.0 \mathrm{mmol}\right)$ was dissolved in methanol/chloroform $(10: 1,20 \mathrm{~mL})$ containing sodium acetate $(0.30 \mathrm{~g}, 2.2 \mathrm{mmol})$. An aqueous solution of $\mathrm{VOSO}_{4} \cdot 5 \mathrm{H}_{2} \mathrm{O}(0.25 \mathrm{~g}$, $1.0 \mathrm{mmol}$ ) was slowly added and a brownish-orange precipitate immediately formed. This was collected by filtration and washed with methanol:water (8:2), methanol and diethyl ether and then dried under vacuum. Yield: $0.30 \mathrm{~g}, 90 \% . \mathrm{C}_{16} \mathrm{H}_{18} \mathrm{~N}_{2} \mathrm{O}_{3} \mathrm{~V}$ (337.27): calcd. C 56.98, H 5.38, N 8.31; found C 56.8, H 5.3, N 8.4.

$\left[\mathbf{V}^{\mathrm{IV}} \mathbf{O}\left\{\mathbf{R}(\boldsymbol{o} \text {-van })_{\mathbf{2}} \mathbf{e n}\right\}\right] \mathbf{( 1 0 ) :}$ The procedure was similar to the one used for 9. Yield: $0.36 \mathrm{~g}, 94 \% . \mathrm{C}_{18} \mathrm{H}_{22} \mathrm{~N}_{2} \mathrm{O}_{5} \mathrm{~V} \cdot 2.1 \mathrm{H}_{2} \mathrm{O}$ (435.17) \{formulation: $\left.\left[\mathrm{V}^{\mathrm{IV}} \mathrm{O}\left\{\mathrm{R}(o \text {-van })_{2} \mathrm{en}\right\}\right]\left(\mathrm{H}_{2} \mathrm{O}\right)_{2.1}\right\}$ : calcd. C $49.68, \mathrm{H}$ 6.07, N 6.44; found C 49.5, H 6.0, N 6.4.

$\mathbf{N a}\left[\mathbf{V}^{\mathrm{V}} \mathbf{O}_{2}\left(\mathbf{R p y r}_{2}\right.\right.$ en) $] \cdot \mathbf{C H}_{3} \mathrm{OH} \cdot 3 \mathrm{H}_{2} \mathrm{O}$ (11): A mixture of $\mathrm{NH}_{4} \mathrm{VO}_{3}$ $(0.03 \mathrm{~g}, 0.27 \mathrm{mmol})$ and $\mathrm{Bu}_{4} \mathrm{NBr}(0.09 \mathrm{~g}, 0.27 \mathrm{mmol})$ in methanol $(10 \mathrm{~mL})$ was heated to reflux for $1 \mathrm{~h}$. The solution turned pale yellow and was filtered to remove the solid materials. After cooling, $\operatorname{Rpyr}_{2}$ en $(0.10 \mathrm{~g}, 0.28 \mathrm{mmol})$ was added and the solution became red. As there was no precipitation after $1 \mathrm{~h}$ of stirring, the solution was maintained at room temperature for 2 weeks. Yellow crystals were collected and characterised by X-ray diffraction.

Physical and Spectroscopic Studies: ${ }^{51} \mathrm{~V}$ and ${ }^{1} \mathrm{H}$ NMR spectra were obtained with a Varian Unity-500 Spectrometer operating at 131.404 MHz and 499.824 MHz, respectively, using a 5-mm broadband probe at $25.0 \pm 0.5^{\circ} \mathrm{C}$. The ${ }^{1} \mathrm{H}$ and ${ }^{51} \mathrm{~V}$ NMR chemical shifts were referenced relative to TSS [sodium 3-(trimethylsilyl)propane sulphonate] at $\delta=0 \mathrm{ppm}$, and to an external $\left[\mathrm{VOCl}_{3}\right]$ solution at $\delta$ $=0 \mathrm{ppm}$, respectively. The ${ }^{51} \mathrm{~V}$ NMR acquisition parameters were as follows: $33 \mathrm{kHz}$ spectral width, $30 \mu$ s pulse width, $1 \mathrm{~s}$ acquisition time and $10 \mathrm{~Hz}$ line broadening. A presaturation pulse sequence was used for ${ }^{1} \mathrm{H}$ NMR spectra to eliminate the residual water signal. IR spectra were recorded with a BioRad FTS 3000 MX FTIR spectrometer. Vis spectra were recorded either with a Hitachi U2000 or with a Perkin-Elmer Lambda 9 UV/Vis/NIR spectrophotometer. The EPR spectra were recorded at $77 \mathrm{~K}$ (on glasses prepared by freezing solutions in liquid nitrogen) with a Bruker ESP 
Table 5. Crystal and structure refinement data

\begin{tabular}{|c|c|c|c|}
\hline & $\mathrm{H}_{2}(o \text {-van })_{2}$ en $(\mathbf{2 A})$ & $\mathrm{KH}(o-\operatorname{van})_{2} \mathrm{en} \cdot 2 \mathrm{H}_{2} \mathrm{O}(\mathbf{2 B})$ & $\begin{array}{l}\mathrm{Na}^{+}\left[\mathrm{VO}_{2}\left(\mathrm{Rpyr}_{2} \mathrm{en}\right)\right]^{-} \cdot \mathrm{CH}_{3} \mathrm{OH} \cdot 3 \mathrm{H}_{2} \mathrm{O} \\
\text { (11) }\end{array}$ \\
\hline Empirical formula & $\mathrm{C}_{18} \mathrm{H}_{20} \mathrm{~N}_{2} \mathrm{O}_{4}$ & $\mathrm{C}_{18} \mathrm{H}_{19} \mathrm{~N}_{2} \mathrm{O}_{6} \mathrm{~K}^{[\mathrm{a}]}$ & $\mathrm{C}_{19} \mathrm{H}_{34} \mathrm{~N}_{4} \mathrm{NaO}_{10} \mathrm{~V}$ \\
\hline Formula mass & 328.36 & 398.45 & 552.43 \\
\hline Temperature $[\mathrm{K}]$ & 293(2) & 293(2) & $293(2)$ \\
\hline Wavelength $[\AA]$ & 1.5418 & 1.5418 & 0.71073 \\
\hline Crystal system & monoclinic & orthorhombic & monoclinic \\
\hline Space group & $P c$ & Pbca & $P 2_{1} / c$ \\
\hline$a[\AA]$ & $9.409(2)$ & $6.498(3)$ & $19.141(2)$ \\
\hline$b[\AA]$ & $6.257(2)$ & $27.155(3)$ & $7.3419(8)$ \\
\hline$c[\AA]$ & $14.436(3)$ & $22.158(3)$ & $19.070(2)$ \\
\hline$\beta\left[^{\circ}\right]$ & $93.19(2)$ & 90 & 114.109(2) \\
\hline$V\left[\AA^{3}\right]$ & $848.6(3)$ & $3910(2)$ & $2446.1(4)$ \\
\hline$Z$ & 4 & 8 & 4 \\
\hline$\rho_{\text {calcd. }}\left[\mathrm{M} \mathrm{gm}^{-3}\right]$ & 1.285 & 1.354 & 1.500 \\
\hline$\mu\left[\mathrm{mm}^{-1}\right]$ & 0.753 & 2.701 & 0.484 \\
\hline$F(000)$ & 348 & 1664 & 1160 \\
\hline$\theta\left[{ }^{\circ}\right]$ & 4.71 to 59.98 & 3.25 to 64.91 & 2.15 to 28.26 \\
\hline Limiting indices & $\begin{array}{l}-10 \leq h \leq 10 \\
-1 \leq k \leq 7 \\
-1 \leq l \leq 16\end{array}$ & $\begin{array}{l}-1 \leq h \leq 7 \\
-31 \leq k \leq 0 \\
0 \leq l \leq 26\end{array}$ & $\begin{array}{l}-25 \leq h \leq 23 \\
-6 \leq k \leq 9 \\
-25 \leq l \leq 25\end{array}$ \\
\hline Measured/unique reflections & $1687 / 1399[R$ (int) $=0.0179]$ & $3495 / 3322[R(\mathrm{int})=0.0516]$ & $15098 / 3823[R(\mathrm{int})=0.0395]$ \\
\hline Refinement method & $\begin{array}{l}\text { Full-matrix least-squares on } \\
F^{2}\end{array}$ & $\begin{array}{l}\text { Full-matrix least-squares on } \\
F^{2}\end{array}$ & Full-matrix least-squares on $F^{2}$ \\
\hline Data/restraints/parameters & $1399 / 2 / 242$ & $3322 / 2 / 332$ & $5859 / 8 / 348$ \\
\hline Goodness-of-fit on $F^{2}$ & 1.054 & 1.118 & 1.029 \\
\hline Final $R$ indices $[I>2 \sigma(I)]$ & $R_{1}=0.0304 ; w R_{2}=0.0839$ & $R_{1}=0.0735 ; w R_{2}=0.1743$ & $R_{1}=0.0488 ; w R_{2}=0.1223$ \\
\hline$R$ indices (all data) & $R_{1}=0.0306 ; w R_{2}=0.0844$ & $R_{1}=0.1049 ; w R_{2}=0.2085$ & $R_{1}=0.0904 ; w R_{2}=0.1447$ \\
\hline Absolute structure parameter & $0.1(2)$ & - & - \\
\hline $\begin{array}{l}\text { Largest difference peak/hole } \\
{\left[\mathrm{e} \AA^{-3}\right]}\end{array}$ & 0.099 and -0.112 & 0.626 and -0.813 & 0.742 and -0.663 \\
\hline
\end{tabular}

[a] The formula of $\mathbf{2 B}$ includes only the hydrogen atoms actually used in the refinement, i.e. H19. Hydrogen atoms of the water molecules were not found or inserted in calculated positions. Taking into account all $\mathrm{H}$ atoms, the correct formula for the compound is $\mathrm{C}_{18} \mathrm{H}_{23} \mathrm{KN}_{2} \mathrm{O}_{6}$.

300E X-band spectrometer. The magnetic susceptibilities were measured in the range 5-296 K using a 7 T F Oxford Instruments system coupled to a Sartorius S3D-V microbalance.

X-ray Crystal Structure Determinations: For compounds $\mathbf{2 A}$ and 2B data were collected with a TURBOCAD4 Enraf-Nonius diffractometer using $\mathrm{Cu}-\mathrm{K}_{\alpha}$ graphite-monochromated radiation. Data were corrected for Lorentz and polarisation effects. No absorption correction was performed. The crystal structures were solved by direct methods (program SIR97 ${ }^{[49]}$ ) and refined with SHELXL97 $7^{[50]}$ using the WinGX package Version 1.64.03b. ${ }^{[51]}$ All non-hydrogen atoms were refined anisotropically. In compound $\mathbf{2 B}$, hydrogen atoms located in the Fourier maps were refined isotropically. In compound $\mathbf{2} \mathbf{A}$, the hydrogen atoms were included in calculated positions and allowed to refine while riding on the parent $\mathrm{C}$ atom except for the hydrogen atoms on $\mathrm{C}(1), \mathrm{C}(2), \mathrm{C}(3)$ and $\mathrm{C}(4)$ which were located and refined isotropically. The poor quality of the crystals of compound $\mathbf{2 B}$ precluded better refinement results. Further details of the crystal structure determinations are given in Table 5. Graphical representations were prepared using ORTEP ${ }^{[49]}$ and Mercury 1.1.2. ${ }^{[52]}$ The X-ray data for compound $\mathbf{1 1}$ were collected with a Siemens Smart $1000 \mathrm{CCD}$ operating at $25^{\circ} \mathrm{C}$. Data were corrected for Lorentz and polarisation effects and for absorption by semiempirical methods. Structures were refined by full-matrix least squares on $F^{2}$. Complex scattering factors were taken from the program package SHELXTL. Of the 15098 reflections measured, 3823 independent reflections exceeded the significance level $|F| \sigma(|F|)>4$.0. Hydrogen atoms were included in calculated positions and were refined in the riding mode except the hydrogen atoms $\mathrm{H}(2 \mathrm{~N}), \mathrm{H}(3 \mathrm{~N}), \mathrm{H}(2 \mathrm{SA}), \mathrm{H}(2 \mathrm{SB}), \mathrm{H}(4 \mathrm{O}), \mathrm{H}(4 \mathrm{SA})$ and
$\mathrm{H}(4 \mathrm{SB})$ which were located from a difference electron density map and then fixed to $0.9 \AA$ from the corresponding heteroatom [except $\mathrm{H}(4 \mathrm{O})$ which was left to refine freely]. Refinement converged with allowance for thermal anisotropy of all non-hydrogen atoms. Crystal data and details of the data collection and refinement are also summarised in Table 5. CCDC-235821, -235822 and -236365 contain the supplementary crystallographic data for this paper for $\mathbf{2 A}$, 2B, and 11, respectively. These data can be obtained free of charge from The Cambridge Crystallographic Data Centre via www.ccdc.cam.ac.uk/data_request/cif.

\section{Speciation Studies}

Spectroscopic Measurements: For preparation of the solutions and $\mathrm{pH}$ calibrations we used a special glass vessel with a double wall with entries for the combined electrode (Radiometer "Red Rod" pHC2015-8), thermometer, nitrogen and reagents (e.g. base). A computerised system developed locally was used to control the titration conditions for $\mathrm{pH}$ calibrations. The emf measurements were made with a Denver Model $15 \mathrm{pH}$ meter.

pH-Potentiometric Titrations: The purity of the ligands was checked $\mathrm{pH}$-potentiometrically and the exact concentrations of the solutions were determined by the Gran method. ${ }^{[53]}$ A stock solution of $\left[\mathrm{V}^{\mathrm{IV}} \mathrm{O}\right]$ was prepared and standardised as reported earlier ${ }^{[54,55]}$ and its $\mathrm{H}^{+}$concentration was determined by $\mathrm{pH}$ potentiometry. The vanadate stock solution was prepared by dissolving $\mathrm{KVO}_{3}$ in a $\mathrm{KOH}$ solution of known molarity. The vanadium content in the commercial $\mathrm{KVO}_{3}$ was determined as reported earlier ${ }^{[15]}$ and the $\mathrm{H}^{+}$concentration in the stock $\mathrm{V}^{\mathrm{V}}$ solution was calculated. All solutions were manipulated under high-purity nitrogen or puri- 
fied argon. The ionic strength was adjusted to $0.20 \mathrm{M} \mathrm{KCl}$ and the temperature was $25.0 \pm 0.1^{\circ} \mathrm{C}$. The $\mathrm{pH}$ was measured with an Orion 710A precision digital $\mathrm{pH}$ meter equipped with an Orion Ross 8103BN type combined glass electrode, calibrated for $\mathrm{H}^{+}$concentration as described earlier. ${ }^{[56]}$ The ionic product of water is $\mathrm{p} K_{\mathrm{w}}$ $=13.76$. Stability constants were determined by $\mathrm{pH}$-metric titration of $10.0-\mathrm{mL}$ samples. The ligand concentrations were in the range $0.002-0.004 \mathrm{M}$ and the metal ion/ligand molar ratio varied from $1: 1$ to $1: 4$. Titrations of solutions containing $\left[\mathrm{V}^{\mathrm{IV}} \mathrm{O}\right]^{2+}$ were normally carried out with $\mathrm{KOH}$ solution of known concentration (ca. $0.2 \mathrm{M}$ ) under purified argon from $\mathrm{pH}=2.0$ up to 11.5 unless very extensive hydrolysis, precipitation or slow equilibration was detected. Titrations of solutions containing $\mathrm{V}^{\mathrm{V}}$ were carried out by backtitrations i.e., by titrating samples from basic $\mathrm{pH}$ with $\mathrm{HCl}$ solutions of known concentration (ca. $0.2 \mathrm{M}$ ). The reproducibility of titration points included in the evaluation was within $0.005 \mathrm{pH}$ units in the whole $\mathrm{pH}$ range. The protonation constants and the ligand purity were determined with the program SUPERQUAD. ${ }^{[41]}$ The concentration stability constants $\beta_{\mathrm{pqr}}=\left[\mathrm{M}_{p} \mathrm{~L}_{q} \mathrm{H}_{r}\right] /[\mathrm{M}]^{p}[\mathrm{~L}]^{q}[\mathrm{H}]^{r}$ were calculated using the PSEQUAD computer program. ${ }^{[40]}$ The formation of the hydroxo complexes of $\left[\mathrm{V}^{\mathrm{IV}} \mathrm{O}\right]$ was taken into account. The following species were assumed: $\left[\mathrm{V}^{\mathrm{IV}} \mathrm{O}(\mathrm{OH})\right]^{+}\left(\log \beta_{10-1}\right.$ $=-5.94),\left[\left(\mathrm{V}^{\mathrm{IV}} \mathrm{O}\right)_{2}(\mathrm{OH})_{2}\right]^{2+}\left(\log \beta_{20-2}=-6.95\right)$, with stability constants calculated from the data of Henry et al. ${ }^{[57]}$ and corrected for the different ionic strength using the Davis equation; $\left[\left(\mathrm{V}^{\mathrm{IV}} \mathrm{O}\right)_{2^{-}}\right.$ $\left.(\mathrm{OH})_{5}\right]^{-}\left(\log \beta_{20-5}=-22.5\right)$ and $\left[\mathrm{V}^{\mathrm{IV}} \mathrm{O}(\mathrm{OH})_{3}\right]^{-}\left(\log \beta_{10-3}=-18.0\right){ }^{[29]}$ For the $\mathrm{V}^{\mathrm{V}}$ systems the stability constants were defined as $\beta_{\mathrm{pqr}}=$ $\left[\mathrm{M}_{p} \mathrm{~L}_{q} \mathrm{H}_{r}\right] /[\mathrm{M}]^{p}[\mathrm{~L}]^{q}[\mathrm{H}]^{r}$, where $\mathrm{M}$ refers to $\left[\mathrm{VO}_{2}\right]^{+}$(not to $\left[\mathrm{HVO}_{4}\right]^{-}$ as is usual in the literature). The speciation of vanadate into monomeric, dimeric, tetrameric, pentameric and decameric species was taken into account and the values used for the stability constants were those of Petterson ${ }^{[59]}$ (after correction for the different ionic strength using the Davis equation, and recalculation using $\left[\mathrm{VO}_{2}\right]^{+}$ as $\mathrm{M})$ : $\left[\mathrm{HVO}_{4}\right]^{2-}\left(\log \beta_{1,0,-3}=-14.93\right),\left[\mathrm{H}_{2} \mathrm{VO}_{4}\right]^{-}\left(\log \beta_{1,0,-2}=-6.76\right)$, $\left[\mathrm{V}_{2} \mathrm{O}_{7}\right]^{4-}\left(\log \beta_{2,0,-6}=-29.71\right),\left[\mathrm{HV}_{2} \mathrm{O}_{7}\right]^{3-}\left(\log \beta_{2,0,-5}=-19.37\right)$, $\left[\mathrm{H}_{2} \mathrm{~V}_{2} \mathrm{O}_{7}\right]^{2-}\left(\log \beta_{2,0,-4}=-10.87\right),\left[\mathrm{V}_{4} \mathrm{O}_{13}\right]^{6-}\left(\log \beta_{4,0,-10}=-37.02\right)$, $\left[\mathrm{HV}_{4} \mathrm{O}_{13}\right]^{5-}\left(\log \beta_{4,0,-9}=-27.67\right),\left[\mathrm{V}_{4} \mathrm{O}_{12}\right]^{4-}\left(\log \beta_{4,0,-8}=-17.80\right)$, $\left[\mathrm{V}_{5} \mathrm{O}_{15}\right]^{5-}\left(\log \beta_{5,0,-10}=-22.63\right),\left[\mathrm{V}_{10} \mathrm{O}_{28}\right]^{6-}\left(\log \beta_{10,0,-16}=-17.32\right)$, $\left[\mathrm{HV}_{10} \mathrm{O}_{28}\right]^{5-}\left(\log \beta_{10,0,-15}=-10.70\right),\left[\mathrm{H}_{2} \mathrm{~V}_{10} \mathrm{O}_{28}\right]^{4-}\left(\log \beta_{10,0,-14}=\right.$ $-6.53)$ and $\left[\mathrm{H}_{3} \mathrm{~V}_{10} \mathrm{O}_{28}\right]^{3-}\left(\log \beta_{10,0,-13}=-4.67\right)$.

\section{Spectroscopic Measurements}

UV/Vis Spectroscopy: For compounds $\mathbf{1 - 1 0}$ the spectra were recorded by dissolving the ligands or complexes in the appropriate solvent (see text). For the $\mathrm{V}^{\mathrm{IV}} \mathrm{O}-\mathrm{R}\left(\mathrm{SO}_{3}-\mathrm{sal}\right)_{2}$ en system, the spectra were recorded upon changing the $\mathrm{pH}$, with approximately fixed total vanadium and ligand concentrations. Two sets of measurements were made with an $\mathrm{L} / \mathrm{M}$ ratio of 1 and with $C_{\mathrm{VO}} \approx 4$ and $12 \mathrm{mM}\left(C_{\mathrm{VO}}=\right.$ total metal ion concentration). The temperature was kept at $25.0 \pm 0.3{ }^{\circ} \mathrm{C}$ with circulating water. In the figures we represent $\varepsilon_{\mathrm{m}}$ values vs. $\lambda$, [where $\varepsilon_{\mathrm{m}}=\operatorname{absorption} /\left(b \cdot C_{\mathrm{VO}}\right), b=$ optical path (either 0.1 - or $1-\mathrm{cm}$ cells were used)]. The spectral range covered was normally $350-900 \mathrm{~nm}$.

EPR Spectroscopy: For the frozen $(77 \mathrm{~K})$ aqueous solution spectra in the absence of ethylene glycol, a relatively broad background was obtained. Most spectra were therefore run with solutions containing 5\% ethylene glycol. The $\mathrm{V}^{\mathrm{IV}} \mathrm{O}$ EPR spectra were simulated using a program from Rockenbauer. ${ }^{[30]}$ The EPR spectra may help to elucidate which groups coordinate in solution. ${ }^{[31]}$ For the $\mathrm{V}^{\mathrm{IV}} \mathrm{O}$ systems, we used the additivity rule to estimate the hyperfine coupling constant $A_{z}^{\text {estim }}$ (and $g_{z}{ }^{\text {estim }}$ ) based on the contributions $A_{z, i}$ (and $g_{\|, i}$ ) of each of the four equatorial donor groups [e.g. $A_{z}^{\text {estim }}$ $\left.=\sum_{i=1}^{4} A_{z, i}\right]$. The estimated accuracy of $A_{z}^{\text {estim }}$ is $\pm 3 \times 10^{-4} \mathrm{~cm}^{-1} \cdot{ }^{[31]}$
These data can be used to establish the most probable binding mode of the ligand in the complexes formed, but care must be taken since the contributions of the donor groups to the hyperfine coupling may depend on their orientation ${ }^{[60]}$ or the charge of the ligand. ${ }^{[61]}$ The influence of the axial donor groups (if any) was not taken into account.

${ }^{1} \mathrm{H}$ and ${ }^{51} \mathrm{~V}$ NMR Spectroscopy: All NMR samples were prepared at room temperature immediately before NMR spectroscopic determinations. Ligand solutions for the NMR $\mathrm{pH}$ titrations were prepared in $\mathrm{D}_{2} \mathrm{O}(99.995 \% \mathrm{D})$ by weighing the appropriate amount of the ligand in order to have the desired concentration. The $\mathrm{pD}$ values of these solutions were adjusted with $\mathrm{DCl}$ and $\mathrm{CO}_{2}$-free $\mathrm{NaOD}$ solutions and measured with a Crison MicropH 2002 pH-meter with an Ingold 405-M5 combined electrode calibrated at $20 \pm 1{ }^{\circ} \mathrm{C}$ with standard buffers at $\mathrm{pH}=4.0$ and 7.0. The final $\mathrm{pH}$ values were corrected for the deuterium isotope effect using $\mathrm{pH}=\mathrm{pD}-$ 0.4. ${ }^{[62]}$ Solutions containing the $\mathrm{V}^{\mathrm{V}}$ complexes were prepared by weighing the appropriate amount of ligand and dissolving it in a $\mathrm{H}_{2} \mathrm{O}$ solution of the vanadate salt of known concentration (with $10 \% \mathrm{D}_{2} \mathrm{O}$ ) to obtain ${ }^{51} \mathrm{~V} \mathrm{NMR}$ spectra, or in a $\mathrm{D}_{2} \mathrm{O}$ solution of the $\mathrm{V}^{\mathrm{V}}$ salt when the samples were analysed by ${ }^{1} \mathrm{H}$ NMR spectroscopy, in order to have the desired L/M ratios. Several sets of experiments as a function of $\mathrm{pH}$ with different $\mathrm{L} / \mathrm{M}$ ratios and total concentrations were carried out. The signal intensities of the NMR resonances were obtained using the program NUTS. ${ }^{[44]}$ After baseline flattening, an iterative deconvolution subroutine (LF) was used to fit the peaks of the spectrum. This subroutine adjusts several parameters, namely the frequency, height, width at half height and area of the selected peaks. The areas obtained may then be used to calculate, for example, the concentrations of the different species.

Supporting Information (see also footnote on the first page of this article): Hydrogen bonding in $\mathrm{H}_{2}(o \text {-van })_{2}$ en (2A), $\mathrm{KH}(o \text {-van })_{2}$ en $\cdot$ $2 \mathrm{H}_{2} \mathrm{O}\left(\right.$ (2B) and $\mathrm{Na}\left[\mathrm{V}^{\mathrm{V}} \mathrm{O}_{2}\left(\mathrm{Rpyr}_{2} \mathrm{en}\right)\right] \cdot \mathrm{CH}_{3} \mathrm{OH} \cdot 3 \mathrm{H}_{2} \mathrm{O}$ (11) (ESI-A), Some IR data for compounds 1-12 (ESI-B), UV/Vis data for the ligands and $\mathrm{V}^{\mathrm{IV}} \mathrm{O}$ complexes prepared (ESI-C), Magnetic susceptibility data for complexes $\mathbf{8}$ and $\mathbf{9}$ (ESI-D), Study of the hydrolytic processes for SB 3 in aqueous solution (ESI-E)

\section{Acknowledgments}

The authors are grateful for the financial support of the Fundo Europeu para o Desenvolvimento Regional, Fundação para a Ciência e Tecnologia, the POCTI Programme (project POCTI/ 35368/QUI/2000), the Hungarian National Research Fund (OTKA T31896/2000), the Hungarian Academy of Sciences and the Hungarian-Portuguese Intergovernmental S \& $\mathrm{T}$ Co-operation Programme. F. A. thanks the Universidade da Coruña for the financial support. This work was carried out within the frame of a COST D21 project. We also thank Rui T. Henriques for the measurement of the magnetic susceptibilities.

[1] K. H. Thompson, J. H. McNeill, C. Orvig, Chem. Rev. 1999, 99, 2561-2571.

[2] K. H. Thompson, C. Orvig, J. Chem. Soc., Dalton Trans. 2000, 2885-2892.

[3] C. Orvig, K. H. Thompson, Coord. Chem. Rev. 2001, 219-221, 1033-1053.

[4] H. Sakurai, Y. Kojima, Y. Yoshikawa, K. Kawabe, H. Yasui, Coord. Chem. Rev. 2002, 226, 187-198.

[5] A. E. Evangelou, Crit. Rev. Oncol. Hematol. 2002, 42, 249-265.

[6] P. Köpf-Maier, Eur. J. Clin. Pharmacol. 1994, 47, 1-16.

[7] C. Djorgevitz, in: Metal ions in biological systems (Eds.: H. Sigel, A. Sigel), Marcel Dekker, New York, 1995, p. 596. 
[8] S. J. D. Karlish, Y. Shechter, Nature 1980, 284, 556-558.

[9] G. R. Dubyak, A. Kleinzeller, J. Biol. Chem. 1980, 255, 53065312.

[10] C. E. Heyliger, A. G. Tahiliani, J. H. McNeill, Science 1985, $227,1474-1477$.

[11] J. Meyerovitch, Z. Farfel, J. Sack, Y. Schechter, J. Biol. Chem. 1987, 262, 6658-6662.

[12] K. H. Thompson, C. Orvig, J. Chem. Soc., Dalton Trans. 2000, 2885-2892.

[13] N. Durai, G. Saminathan, J. Clin. Biochem. Nutr. 1997, 22, 3139.

[14] J. M. Lacoste, J. Duhault, D. Ravel, EUR Pat. Appl., 1993, EP $521,787$.

[15] I. Correia, J. Costa Pessoa, M. T. Duarte, R. T. Henriques, M. F. M. Piedade, L. F. Veiros, T. Jackush, A. Dornyei, T. Kiss, M. M. C. A. Castro, C. F. G. C. Geraldes, F. Avecilla, Chem. Eur. J. 2004, 10, 2301-2317.

[16] D. Rehder, J. Costa Pessoa, C. F. G. C. Geraldes, M. M. C. A. Castro, T. A. Kabanos, T. Kiss, B. Meier, G. Micera, L. Pettersson, M. Rangel, A. Salifoglou, I. Turel, D. Wang, J. Biol. Inorg. Chem. 2002, 7, 384-396.

[17] D. F. Evans, P. H. Missen, J. Chem. Soc., Dalton Trans. 1987, 1279-1281.

[18] Y. Mo, G. Yang, G. Zhao, B. Li, Jinlin Daxue Ziran Kex. Xue. 1990, 93-1; this is the journal where the structure was published but it was impossible to obtain so we refer to this structure with the reference code of the Cambridge Structural Database: VOJSUI.

[19] N. P. Pahor, M. Calligaris, D. Nardin, L. Randaccio, Acta Crystallogr. Sect. B 1978, 34, 1360-1363.

[20] A. Palmer, F. Brisse, Acta Crystallogr., Sect. B 1980, 36, 14471452.

[21] D. Cunningham, K. Gilligan, M. Hannon, C. Kelly, P. McArdle, A. O'Malley, Organometallics 2004, 23, 984-994.

[22] Since no cif file is presently available for this crystal structure, neither from CCDC nor from the supplementary data, it was not possible to access these data to make adequate comparisons. We may deduce that the structure is different since only one half of the molecule is found in the asymmetric unit. The molecule itself seems more planar and so the conformation as well as the packing are different.

[23] K. Nakamoto, Infrared and Raman Spectra of Inorganic Compounds, Part B, 5th ed., John Wiley \& Sons, New York, 1997, pp. 73-271.

[24] G. Socrates, Infrared and Raman Characteristic Group Frequencies. Tables and Charts, John Wiley \& Sons, Chichester, 2001, pp. 108-113.

[25] B. Bosnich, J. Am. Chem. Soc. 1968, 90, 627-632.

[26] M. Gullotti, A. Pasini, P. Fantucci, R. Ugo, R. D. Gillard, Gazz. Chim. Ital. 1972, 102, 853-892.

[27] H. E. Smith, J. R. Neergaard, E. P. Burrows, F. M. Chen, J. Am. Chem. Soc. 1974, 96, 2908-2916.

[28] K. S. Patel, G. A. Kolawolen, A. Earnshaw, J. Inorg. Nucl. Chem. 1981, 43, 3107-3112.

[29] L. F. Vilas Boas, J. Costa Pessoa, Vanadium, in Comprehensive Coordination Chemistry (Eds.: G. Wilkinson, R. D. Gillard, J. A. McCleverty), Pergamon Press, Oxford, 1987, pp. 453-583.

[30] A. Rockenbauer, L. Korecz, Appl. Magn. Reson. 1996, 10, 2943.
[31] N. D. Chasteen, in Biological Magnetic Resonance (Eds.: J. Lawrence, L. J. Berliner, J. Reuben), Plenum, New York, 1981, vol. 3, pp. 53-119.

[32] C. R. Cornman, K. M. Geiser-Bush, S. P. Rowley, P. D. Boyle, Inorg. Chem. 1997, 36, 6401-6408.

[33] B. J. Hamstra, L. P. Houseman, G. J. Colpas, J. W. Kampf, R. Lobrutto, W. D. Frasch, V. L. Pecoraro, Inorg. Chem. 1997, 36, 4866-4874.

[34] P. W. Selwood, Magnetochemistry, Interscience, New York, 1956.

[35] K. S. Patel, G. A. Kolawole, J. Coord. Chem. 1982, 11, 231237.

[36] C. J. Carrano, C. M. Nunn, R. Quan, J. A. Bonadies, V. L. Pecoraro, Inorg. Chem. 1990, 29, 944-951.

[37] Y. Kuge, S. Yamada, Inorg. Chim. Acta 1977, 21, 85-88.

[38] H. Kumagai, M. Arishima, K. Susumu, K. Ymada, S. Kawata, S. Kaizaki, Inorg. Chem. 2002, 41, 1989-1992.

[39] A. Mederos, Polyhedron 1997, 16, 4191-4196.

[40] L. Zekany, I. Nagypál, in Computational Methods for the Determination of Stability Constants (Ed.: D.Leggett), Plenum, New York, 1985, pp. 291-353.

[41] P. Gans, J. Chem. Soc., Dalton Trans. 1985, 1195-1200.

[42] A. Gergely, I. Sóvágó, Inorg. Chim. Acta 1976, 20, 27-32.

[43] D. Rehder, Inorg. Chem. 1988, 27, 584-587.

[44] NUTS, NMR spectroscopic data processing software, Acorn NMR spectroscopy, 1999.

[45] D. C. Crans, P. K. Shin, J. Am. Chem. Soc. 1994, 116, 13051315.

[46] A. S. Tracey, H. Li, M. J. Gresser, Inorg. Chem. 1990, 29, $2267-$ 2271.

[47] S. N. Poddar, K. Day, S. C. N. Sarkar, J. Indian Chem. Soc. 1963, 40, 489-490.

[48] D. F. Evans, P. H. Missen, J. Chem. Soc., Dalton Trans. 1987, $1279-1281$.

[49] L. J. Farrugia, J. Appl. Crystallogr. 1997, 30, 565.

[50] G. M. Sheldrick, SHELXL-97, Programs for Crystal Structure Analysis, release 97-2, University of Göttingen, Germany, 1997.

[51] L. J. Farrugia, J. Appl. Crystallogr. 2002, 32, 837-838.

[52] I. J. Bruno, J. C. Cole, P. R. Edgington, M. Kessler, C. F. Macrae, P. McCabe, J. Pearson, R. Taylor, Acta Crystallogr., Sect. $B$ 2002, 58, 389-397.

[53] G. Gran, Acta Chem. Scand. 1950, 4, 559-575.

[54] J. Costa Pessoa, L. F. Vilas Boas, R. D. Gillard, R. Lancashire, Polyhedron 1988, 7, 1245-1262.

[55] I. Nagypál, I. Fábián, Inorg. Chim. Acta 1982, 61, 109-113.

[56] J. Costa Pessoa, T. Gajda, R. D. Gillard, T. Kiss, S. M. Luz, J. J. G. Moura, I. Tomaz, J. P. Telo, I. Torok, J. Chem. Soc., Dalton Trans. 1998, 3587-3600.

[57] R. P. Henry, P. C. H. Mitchell, J. E. Prue, J. Chem. Soc., Dalton Trans. 1973, 1156-1159.

[58] A. Komura, M. Hayashi, H. Imanaga, Bull. Chem. Soc. Jpn. 1977, 50, 2927-2931.

[59] L. Pettersson, B. Hedman, L. Andersson, N. Ingri, Chem. Scr. 1983, 22, 254-264

[60] T. S. Smith, C. A. Root, J. W. Kampf, P. G. Rasmussen, V. L. Pecoraro, J. Am. Chem. Soc. 2000, 122, 767-775.

[61] A. J. Tasiopoulos, A. N. Troganis, A. E. Evangelou, C. P. Raptopoulou, A. Terzis, Y. Deligiannakis, T. A. Kabanos, Chem. Eur. J. 1999, 5, 910-921.

[62] P. K. Glasoe, F. A. Long, J. Phys. Chem. 1960, 64, 188-190. Received: June 7, 2004 